Journal of Educational

and Psychological Sciences

Volume (5), Issue (44): 30 Nov 2021

P: $128-152$

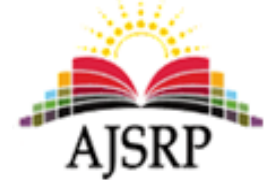

ISSN: 2522- 3399

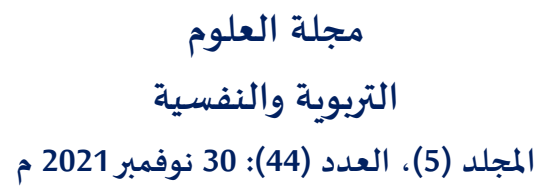

ص: 128 - 152

\title{
The Relationship Between Principals' Patterns of Leadership According to Blanchard and Hersey Theory and The Level of Teacher's Job Satisfaction in the Directory of Education in Amman First Area
}

\section{Faten Saleem Eid}

Ministry of Education || Jordan

\begin{abstract}
This study aimed at identifying the relationship of leadership pattern with the satisfaction of their teachers in the Directorate of Education in Amman First Area' as well as finding if there are any specialty, secondary school principal pattern, and the interaction between them, The study objectives are to answer the following questions:

1. What are the leadership patterns of the secondary school principals according to Blanchard and Hersey theory?

2. What is the extent of job satisfaction among teachers?

3. Are there any significant differences for job satisfaction and the secondary school principal pattern concerning teacher specialty and the interaction between them?

4. Are there any significant differences for job satisfaction and the leadership pattern of school principal and the interaction between?

5. There were differences in satisfaction resulted of the specialty factor, while other differnces resulted of the secondary school principal's leadership pattern and there was no interaction between specialty and the leadership pattern of the principals.
\end{abstract}

The study recommended that:

1. There should be concentration on the selling leadership pattern, as well as concentrating on the participation of the teacher in decision making and meet their needs and wells.

2. Training the managers on the suitable leadership patterns and develop them vocationally.

3. To find out the reasons of the satisfaction of male teacher concerning the teaching process and find the solutions.

4. Increase the level of satisfaction for teachers through the enrichment of their spiritual level and support their position in society.

5. Performing more studies concerning the leadership pattern and the job satisfaction including the factors not included in this study such as age, marital status, work place, and salary.

Keywords: leadership style- school principals- Blanchard and Hersey Theory-job satisfaction- secondary school teachers.

$$
\begin{aligned}
& \text { علاقة النمط القيادي لمديري المدارس حسب" نظرية بلا نشرد وهيرسي" } \\
& \text { بمستوى الرضا الوظيفي لمعلمي المرحلة الثانوية بمديرية التربية والتعليم للواء ماركا } \\
& \text { فاتن سليم عيد } \\
& \text { وزارة التربية والتعليم || الأردن }
\end{aligned}
$$


المستخلص: هدفت هذه الدراسة إلى التعرف على النمط القيادي لمديري المدارس الثانوية، وعلاقة النمط القيادي لمديري المدارس المارس

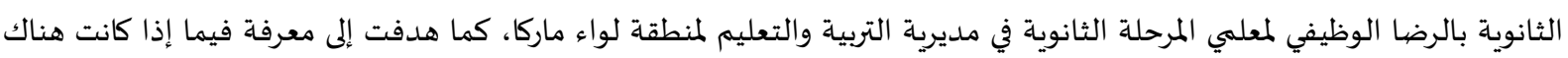

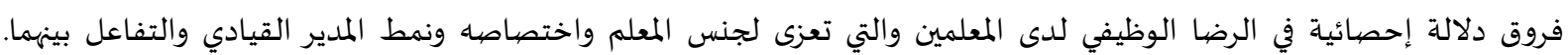

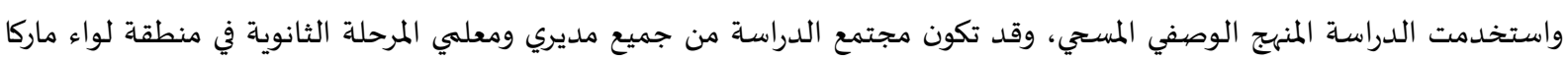

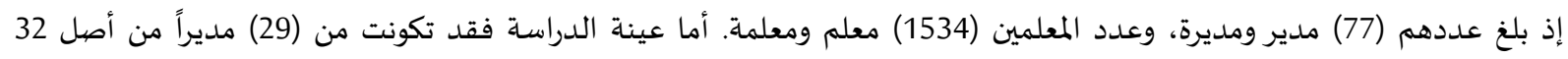

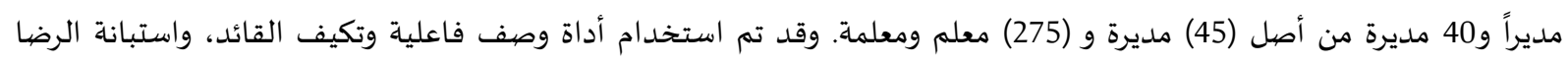

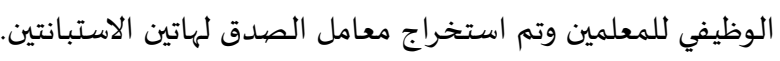

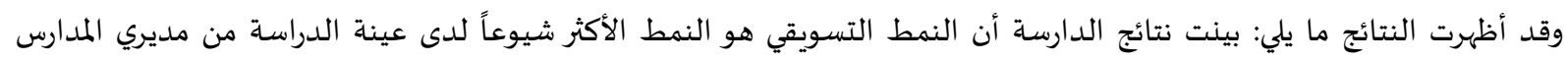

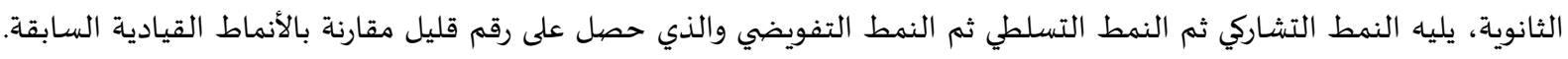

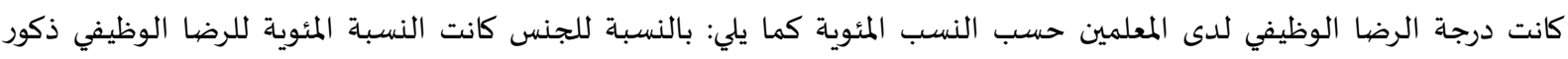

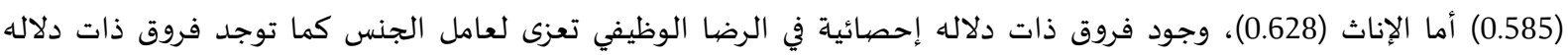

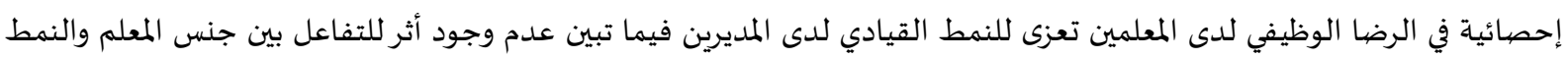

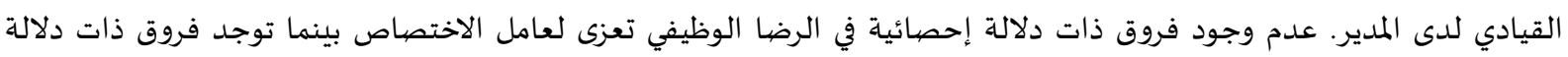

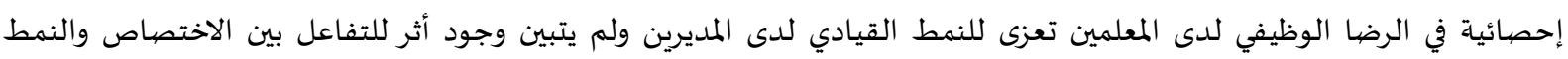
القيادي لدى المديرين.

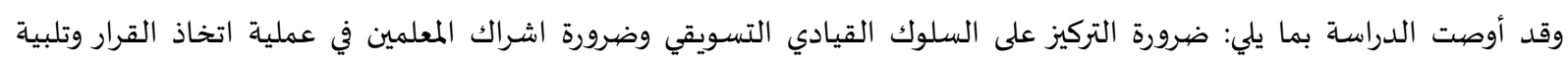

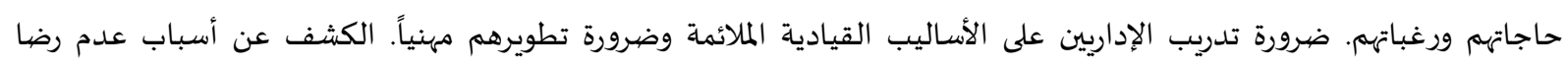

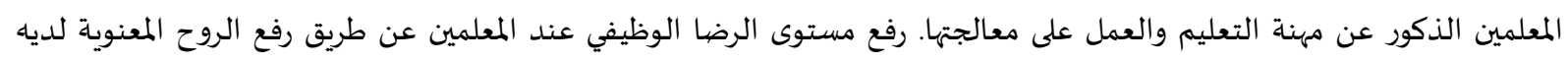

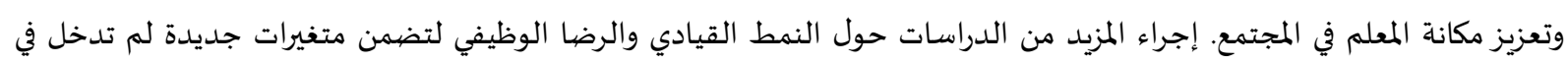

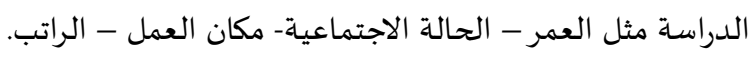

الكلمات المفتاحية: النمط القيادي- مديري المدارس- نظرية بلا نشرد وهيرسي- الرضا الوظيفي- معلمي المرحلة الثانوية.

المقدمة.

كانت الإدارة في الماضي تتسم بالبساطة وعدم التعقيد نظراً لبساطة المؤسسات ومحددودية وظائفها، وتعتمد على الخصائص والسمات الشخصية للقائد. وقد بدأت الإدارة تتطور بتطور المعطيات الاقتصادياة والاجتيتماعية التي

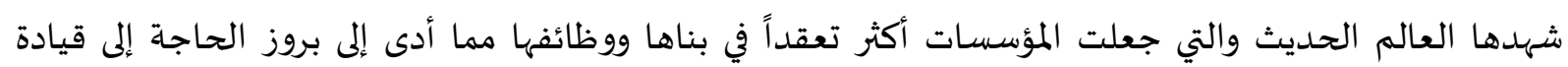
فاعلة تضمن حسن سير المؤسسة وضيمان كفايتها وفاعليتها. وقد تطورت النظرية العلمية في الإدارة بفضل دراسات تايلر وفايول Taylor and fayol|لتي ركزت على على وفاعلى

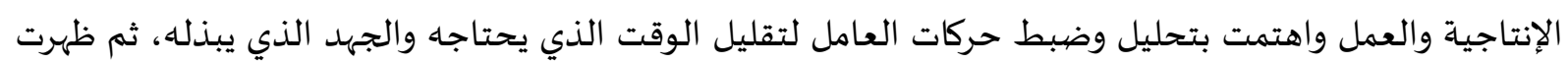

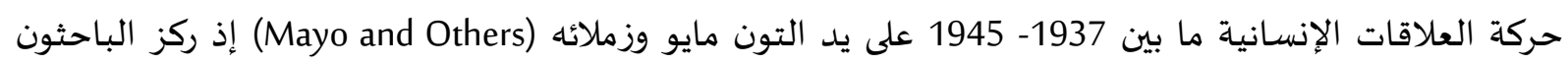

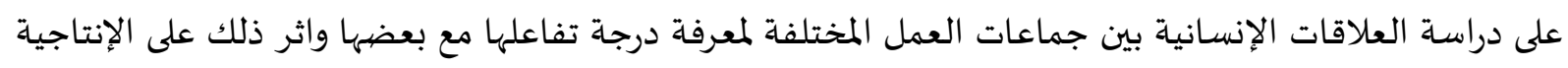

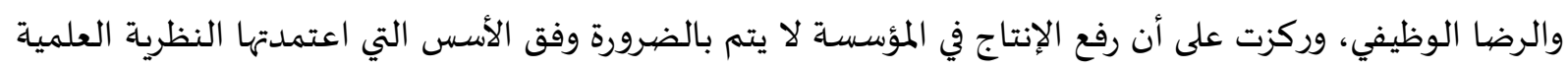

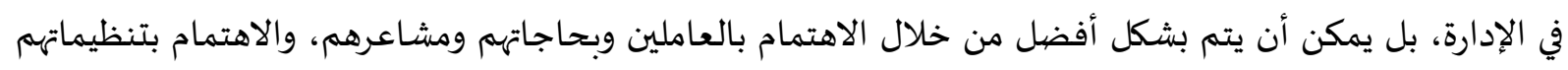
الرسمية (كامل والبكري، 1990).

ومع هذا التوسع في مفهوم الإدارة تفرعت الإدارة إلى فروع عدة ومن هذه الفروع الإدارة التربوية التي تخدم

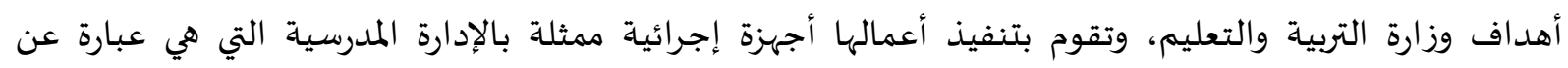

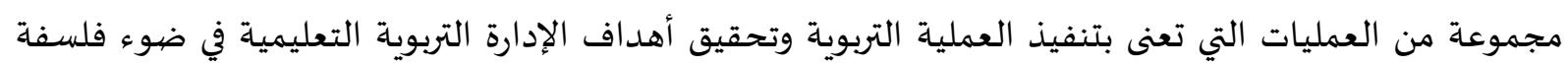


النظام العام للدولة مستخدمة الإمكانيات البشرية والمادية والوسائل التقنية التعليمية لتحقيق الأهداف المحددة للتربية. (شوقي، 1992).

إذا يرى هاريس (Harris): أن الإدارة هي تنسيق الجهود البشرية المختلفة من أجل تحقيق هدف معين

(الشلعوط، 1994).

أما هوج (Hodge) فيرى أن الإدارة هي عملية توجيه الجهود البشرية لتحقيق الأهداف العامة للجهاز

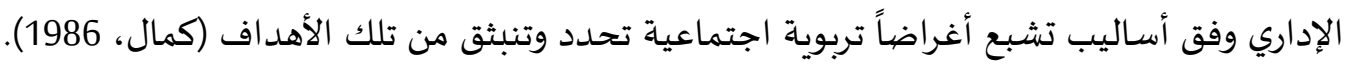

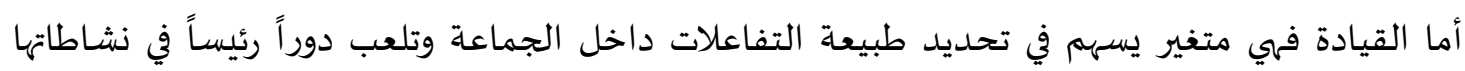

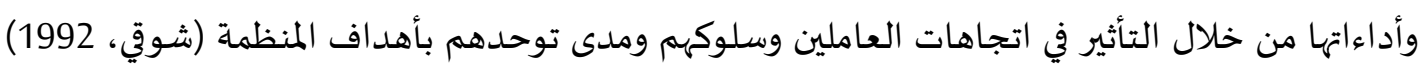

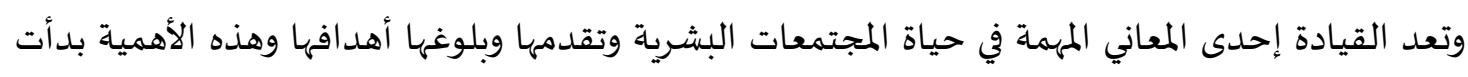

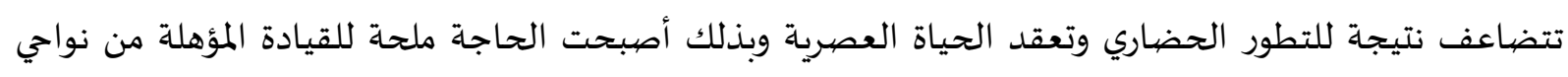

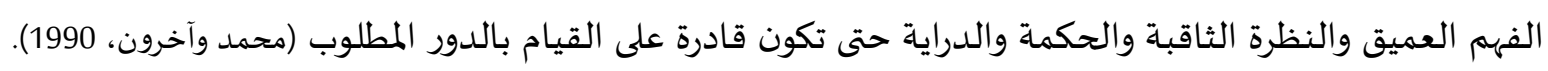

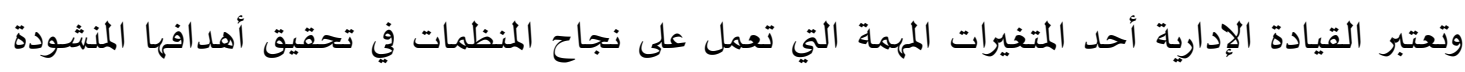

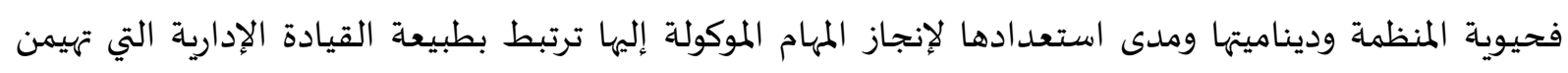

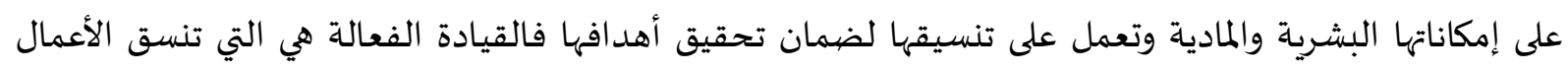
وتوجه الجهود وتحفز الأفراد نحو تحقيق أهداف المنظمة. ويفرق كوزيس وبوستر بين القيادة والإدارة فالقيادة عندهما هي جعل الأخرين يريدون أن يعملوا أما الإدارة فهي جعل الأخرين يعملون عن طريق اصددار الأوامر والتعليمات الواجب عليهم الامتثال لها (Kouzes and Posner, 1987).

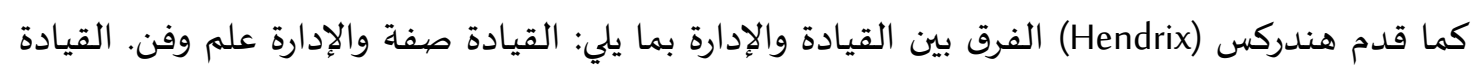

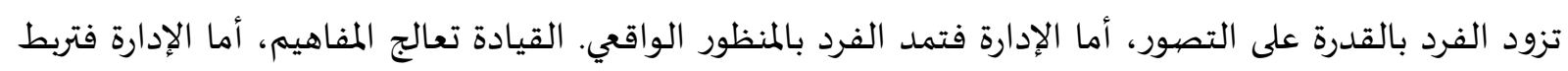

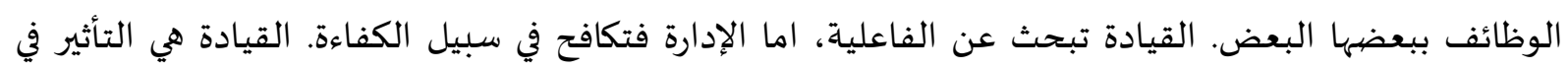

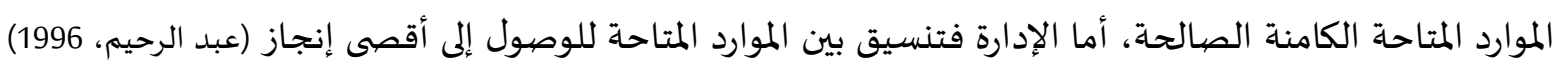

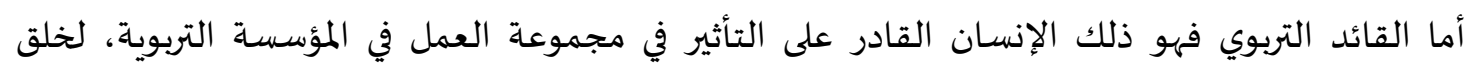

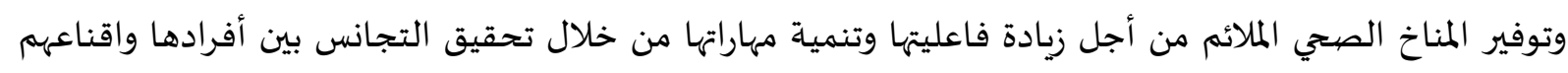

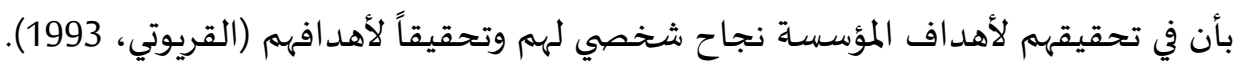

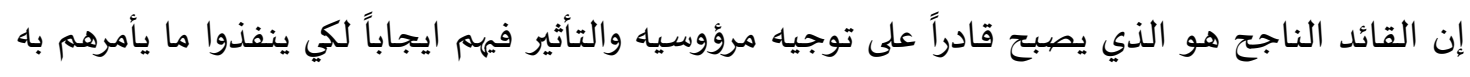
أو يشير عليهم بتنفيذه، وهو من يستطيع كسب تعاون العاملين معاه وتحقيق التجانس بينهم واقناعهم بأن تحقيقهم لأهداف المنظمة نجاح شخصي لهم وتحقيقاً لأهد افهم.

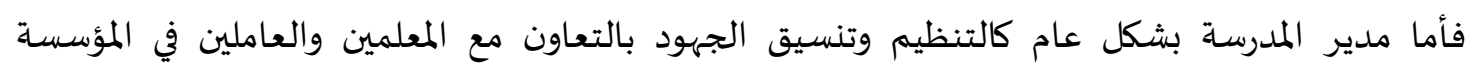
التربوية. (نبراوي، 1989). من هنا يأتي الاهتمام بالمدرسة فلسفة وأهدافاً وتقويماً والاهتمام بمديري المدارس الذين يمارسون أدوار

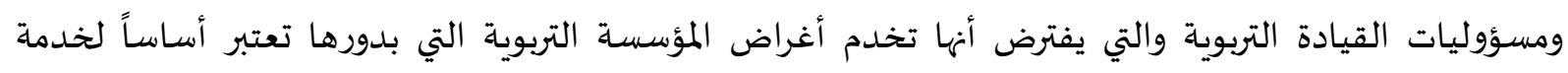

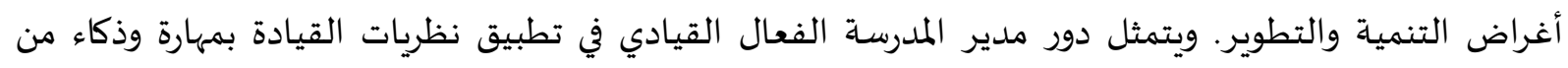

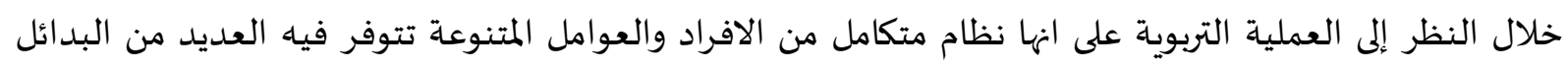

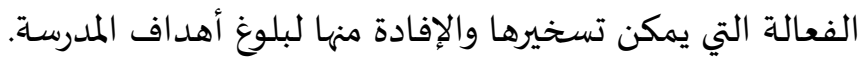


فمدير المدرسة الفعال هو القائد القادر على التأثير في مخرجات الجماعة، التي تعني تحقيق الأهداف للمؤسسة والجماعة، كما يعمل على رضا أعضائه وارتفاع الروح المعنوية لديهم. فالمدير كما يقول فيلبس (Philips)

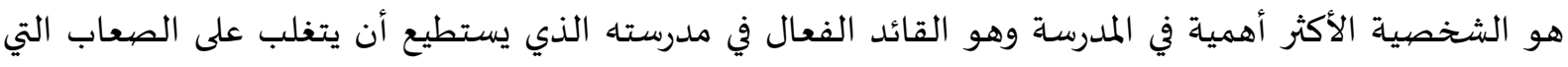

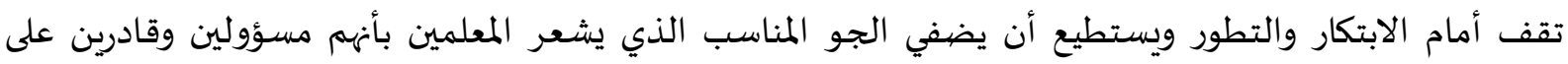

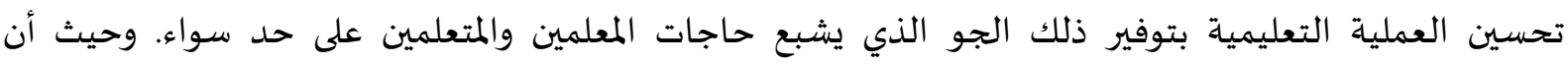

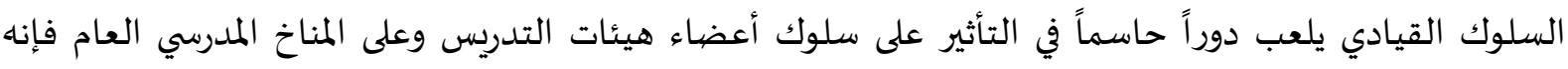

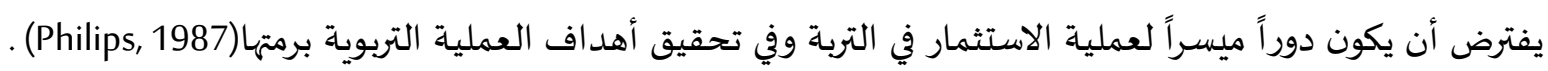

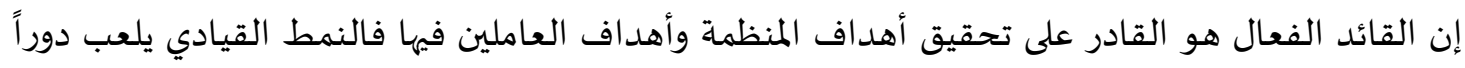

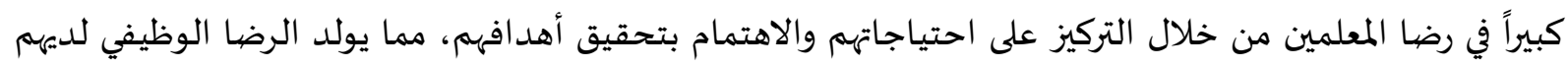

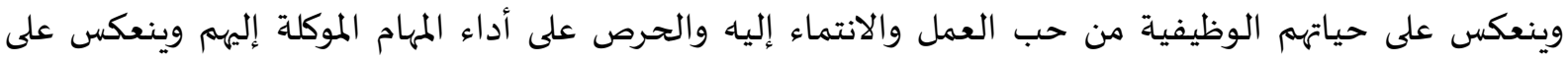

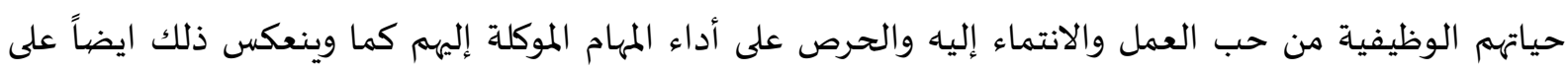

$$
\text { سلوكهم خارج المدرسة. }
$$

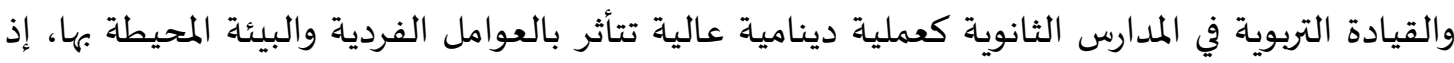
ان تمركز معظم تلك المدارس في منطقة عمان ذات الكثافة العالية نسبياً والمتنوعة والتي تشهد تغييراً وتطويراً

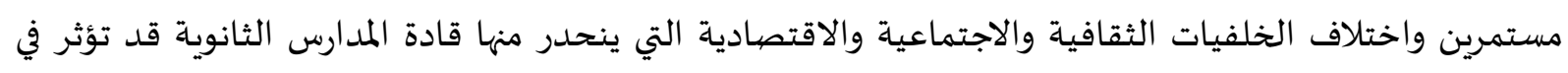

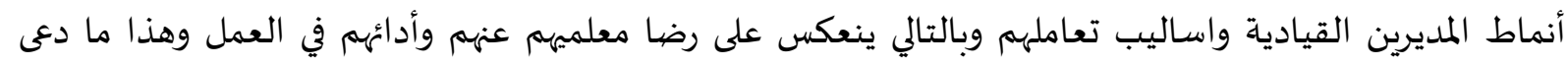

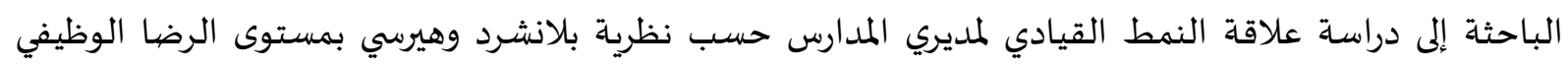

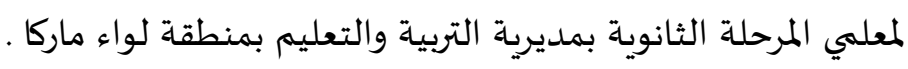

مشكلة الدراسـة:

يختلف المديرون في انماطهم القيادية تبعاً للعديد من المتغيرات والعوامل، وسواء ادرك المديرون أم لا فإن

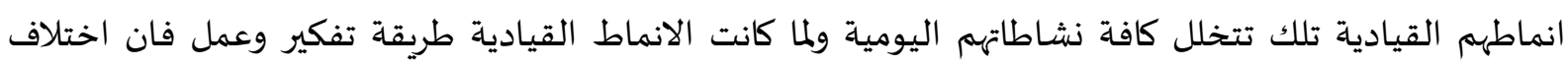

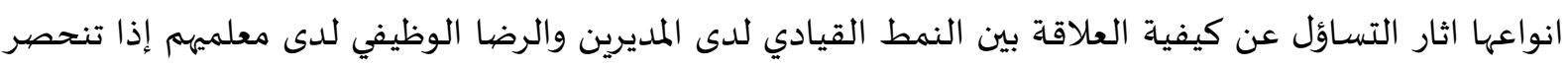

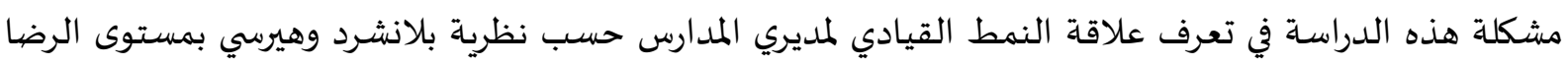
الوظيفي لمعلمي المرحلة الثانوية بمديرية التربية والتعليم لمنطقة لوراء لواء ماركا.

أسئلة الدراسـة:

تتحدد مشكلة الدراسة في الأسئلة الآتية:

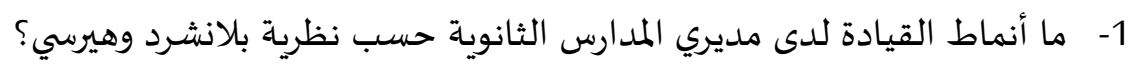

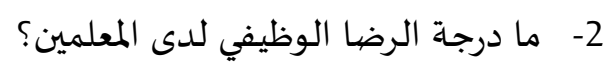
3- هل توجد فروق ذات دلالة إحصائية في الرضا الوظيفي لدى المعلمين تعزى لمتغير جنس المعلم ونمط المدير لماير القيادي والتفاعل بينهما؟ 4- - هل توجد فروق ذات دلالة إحصائية في الرضا الوظيفي لدى المعلمين تعزى لاختصاص المعلم ونمط المدير

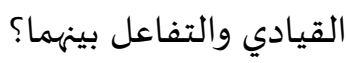


تهدف هذه الدراسة إلى التعرف على الأنماط القيادية لدى مديري المدارس الثانوية، كما تهدف إلى التعرف

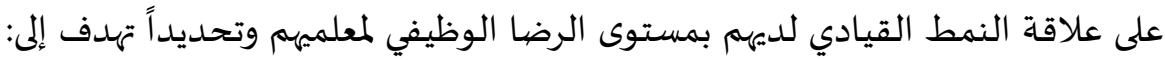

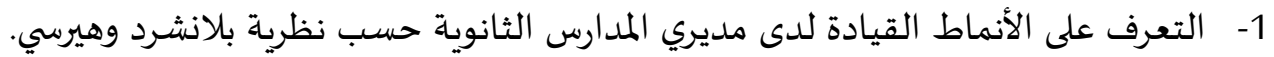

2- التعرف على درجة الرضا الوظيفي لدى المعلمين.

3- التعرف على مدى وجود فروق ذات دلالة إحصائية في الرضا الوظيفي لدى المعلمين تعزى لمتغير جنس المعلم

ونمط المدير القيادي والتفاعل بينهما.

4- التعرف على مدى وجود فروق ذات دلالة إحصائية في الرضا الوظيفي لدى المعلمين تعزى لاختصاص المعلم

ونمط المدير القيادي والتفاعل بينهما.

أهمية الدراسة:

تتصف القيادة في المنظمات التربوية، ذات الطبيعة الإنسانية كالمدارس، بدينامية عالية وتتطلب فهماً واعياً

ومتعمقاً لكافة ابعادها الإنسانية والوظيفية وقدرة عالية على حسن التعامل مع معطياتها.

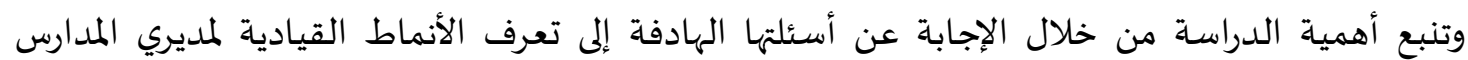

الثانوية وأثرها في الرضا الوظيفي لمعلمي المرحلة الثانوية بمديرية التربية والتعليم لمنطقة لواء ماركا، وتوضيح العوامل التي تؤثر سلباً او إيجاباً على رضا المعلمين، وكذلك التعرف على المائل الأنماط القيادية لمدير المدارس وأثرها على الرضا

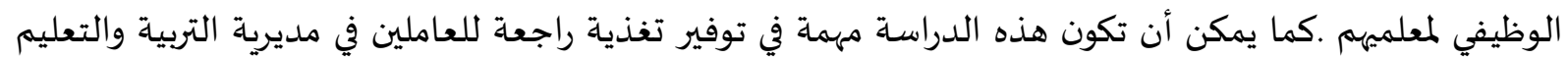

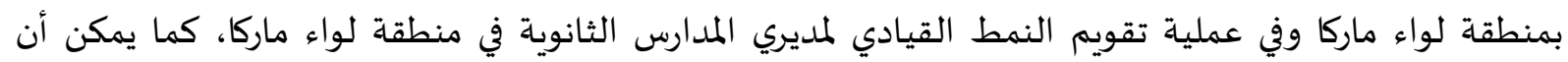
تضيف نتائج هذه الدراسة أهمية خاصة لبرامج تدريب مديري المدارس الثانوية من خلال التركيز على السلوك الذي تلفي

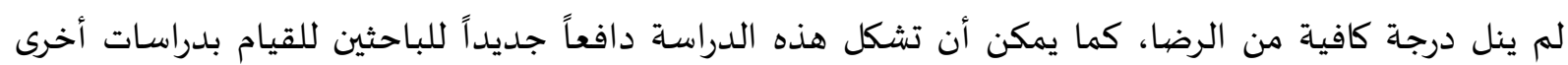

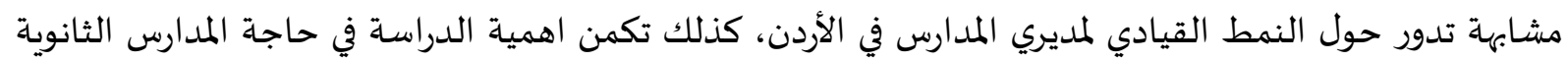

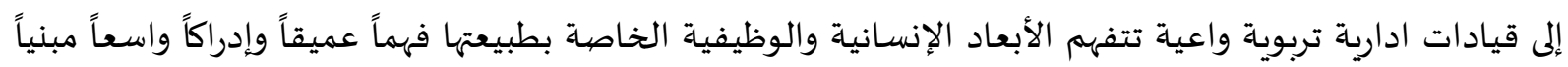

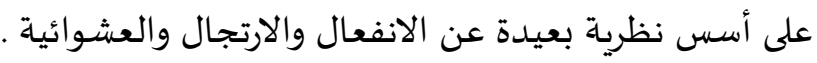

حدود الدراسة

اقتصرت هذه الدراسة على الحدود الآتية:

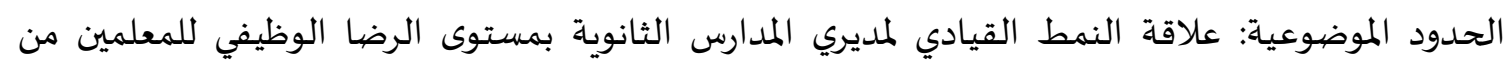
منظور نموذج القيادة الموقفية لبلانشردوهيرسي. الحدود البشرياة: عينة بلغت (275) من مديري ومعلمي المرحلة الثانوية.

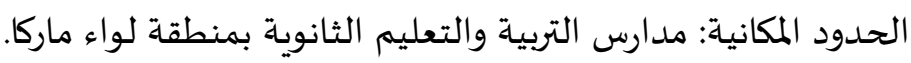

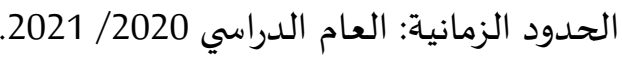

التعريفات الاصطلاحية والإجرائية:

اشتملت الدراسـة على عدد من التعريفات المتعلقة بموضواتهرع الدراسـة والتي هي:

- القيادة (leadership): إجراء يؤثر في سلوك الأفراد وفي تصرفاتهم وسعيهم للوصول إلى الخطة المحددة

المرغوب فيها (Lovell and Willes, 1983). 
- كما تعرف بأنها: "مجموعة من العمليات التي يقوم بها القائد للتأثير على نشاط مجموعة منظمة تجاه تحديد او إنجاز هدف معين (آل ناجي، 2016). النمط القيادي (leadershipstyle): هو جملة السلوك والإجراءات التي يمارسها المدير والتي تؤثر في نشاطات

الأفراد العاملين في المؤسسة لتحقيق الأهداف المنشودة للمؤسسة في ظروف معينة (المغيدي، ناجي، 1994) وعرف الحراحشة (2016) النمط القيادي: بأنه الأسلوب الذي يمارسه القائد للتأثير على الآخرين وتوجيه سلوكهم. - الرضا الوظيفي (Job satisfaction): هو شعور تجاه الجوانب التي بالإمكان تمييزهما وتحديدها من الموقف الوظيفي او وضع الوظيفة ككل (1990، Muchinsky). كما يعرف الرضا الوظيفي بأنه: الدرجة التي يتلاق او يزيد فيها الإشباع الفعلي من العمل في مهنة التدريس

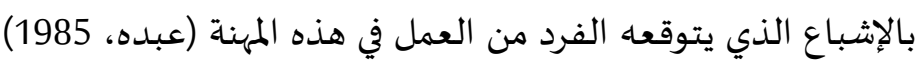

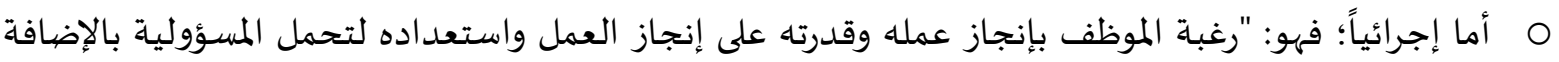
إلى خبرة الموظف في مجال عمله ومؤهلاته الأكاديمية.

2- 2 - 2 الإطار النظري والدراسـات السـابقة اولاً - الإطار النظري: قام الباحثون بتركيز جهودهم لدراسة النمط القيادي وأثره على سلوك العاملين، فقد رأى ستيورات

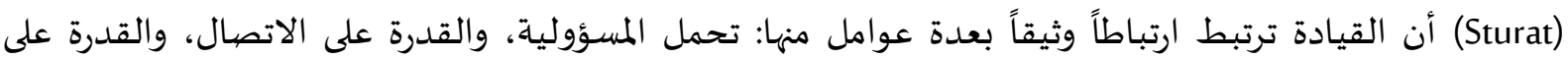

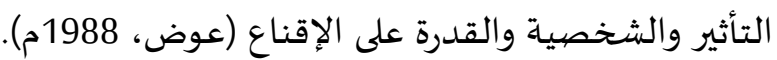
ويرى بلانشرد وهيرسي (Blanchard\& Hersey) أن النمط القيادي هو جملة السلوك والإجراءات التي يمارسها المدير للتأثير في نشاطات المعلمين والعاملين في المدرسة. ومن هنا فإن النمط القيادي للقائد الجيد يتميز بتسهيل العلاقات وتحقيق التفاعل المستمر بين أفراد الجماعاة، ولقد حدد عباس عوض هذه الصفات بما يلي: الدفء والصداقة، ويسترضي اتباعه ويبدد الصراع ويزيل التوتر، ويقدم المساعدة الشخصية ولمدية لمن يحتاجها كما يرشد ويستمع ويظهر الفهم ويتحمل وجهات النظر المختلفة، يقبل أعضاء جماعته ويحترمهم ايضاً

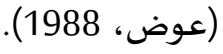

اولاً: تحقيق أهداف وغايات: إذ يشمل النمط القيادي الموجاه نحو تحقيق أهداف الجماعة وغاياتها من خلال: تقديم الاقتراحات العملية

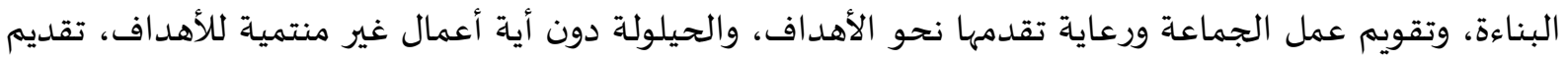
بدائل الحلول التي تساهم في تحقيق تلك الأهداف.

ثانياً: صيانة وتعزيز قوة الجماعة وتماسكها يشمل النمط القيادي الموجه نحو الحفاظ على تماسك الجماعة وصيانتها وتعزيزها من خلال حفز الأعضاء

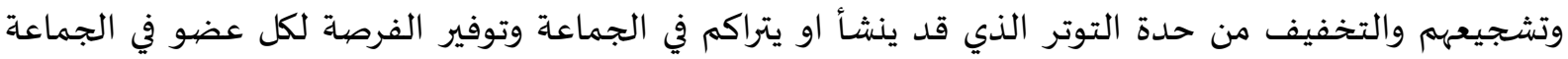

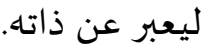




$$
\text { لقد ظهرت العديد من النظريات القيادية ومنها: }
$$

1- نظريات السمات والرجل العظيم Traits and Great Man Theories: تقوم هذه النظريات على افتراض مفاده بأن هناك مجموعة من الخصائص التي تفسر القدرات القيادية عند البعض وهو في مجموعها تكون ما يمكن

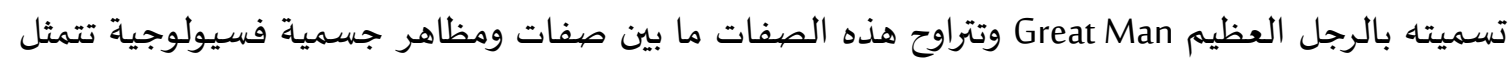

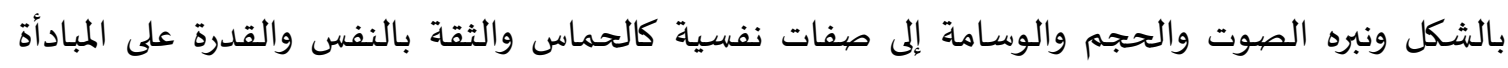

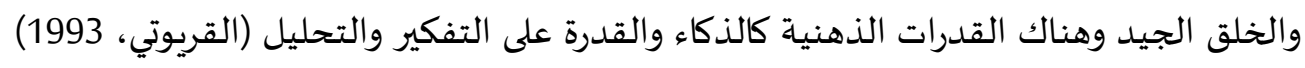
2- النظرية السلوكية: Behavioral Theory: تؤكد هذه النظرية على المنهج التحليلي في دراسة القيادة أي التركيز

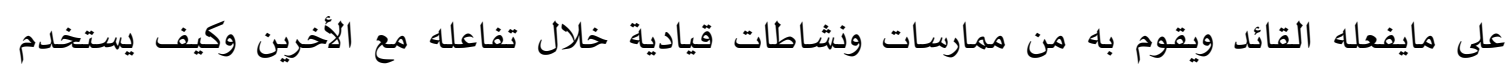

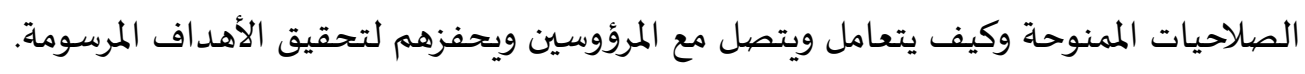

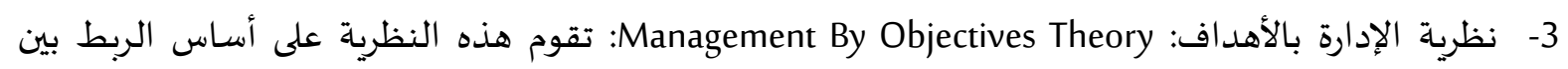
النمط القيادي ودافعية مشاعر المرؤوسين باعتبارها المحدد الرئيس للنمط القيادي من حيث قدرته على فهره

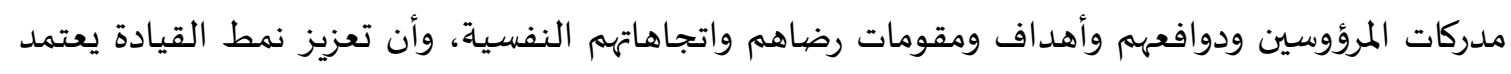

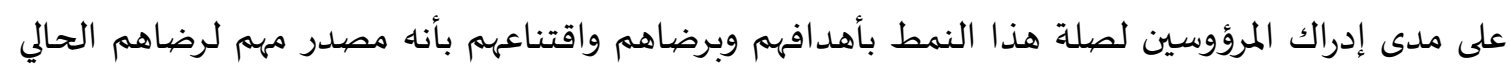
المستقبلي. 4- نظرية بلانشرد وهيرسي Blanchard's \& Hersey Theory: لقد قام كينيث بلانشرد وباول هيرسي بتطوير نموذج

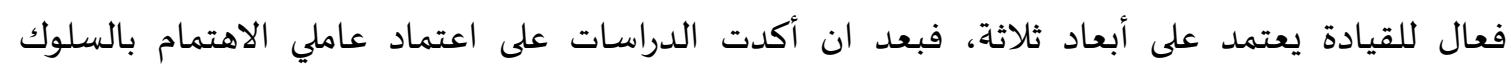

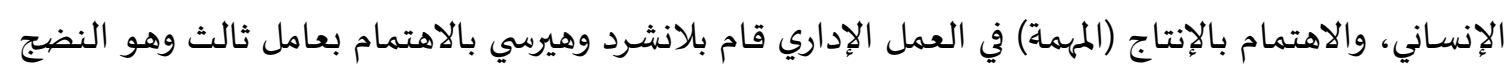

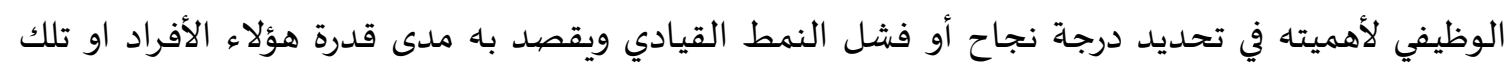

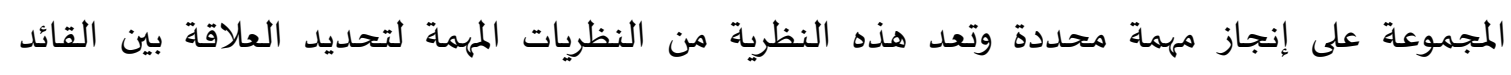

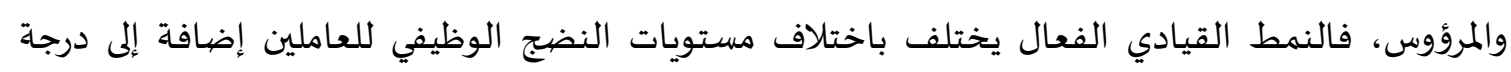

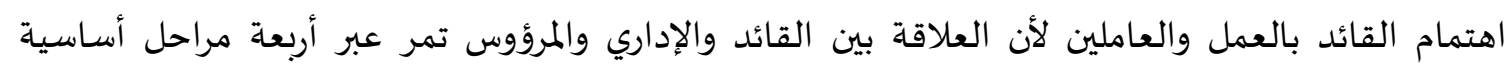
تسمى بمراحل النضج الوظيفي وهي على النحو التالية:

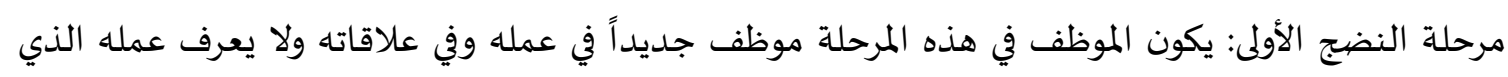
سوف يقوم باه. مرحلة النضج الثانية: مع مرور الوقت يكتسب الموظف الخبرة ويكون قادر على القيام بعمله ولديه بعض المض لموله الاستعداد لتحمل المسؤولية.

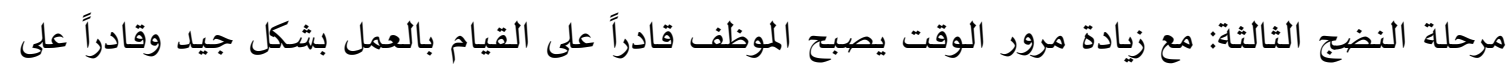

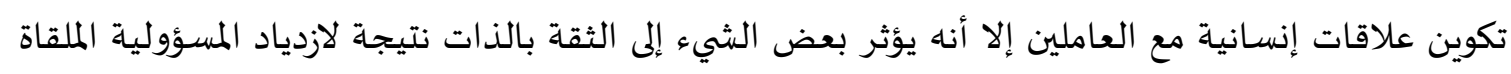
عليه. مرحلة النضج الرابعة: يكون الموظف في هذه المرحلة قد اكتملت قدراته بشكل عال ويقوم بعمله على أحسن

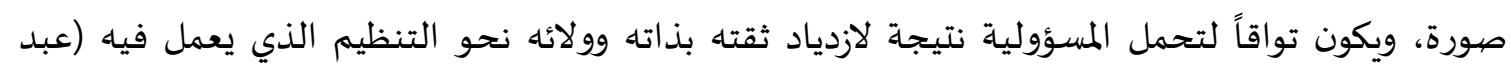
الباري دره وآخرون، 1994). 
وقد قسم بلانشرد وهيرسي مستوى النضج الوظيفي للمعلم إلى أربعة مستويات هي: قدرات ومهارات متدنية

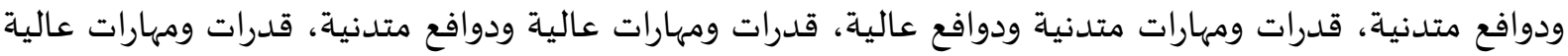
ودوافع عالية.

لذلك فإن فاعلية النمط هي انعكاس لملاءمته لمستوى النضج الوظيفي للمعلم في موقف محدد

(المغيدي، 1996).

إن نظرية بلانشرد وهيرسي تشكل إطاراً مفهومياً مفيداً للقيادة الموقفية، وتبين بأنه لا وجود للنمط القيادي

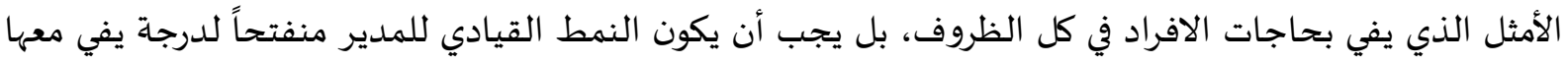

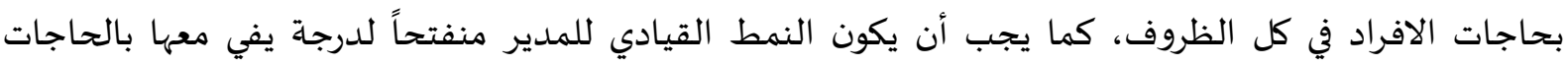
المتغيرة للمرؤوسين والظروف المحيطة بهم، فالمدير الفعال هو الذي يغير نمطه القيادي كلما تغير مستوى النضج لهيج الوظيفي لمرؤوسياء.

ويرتبط بنظرية بلانشرد وهيرسي موضهوع على درجة عالية من الأهمية وهو الرضا الوظيفي، حيث يعتبر

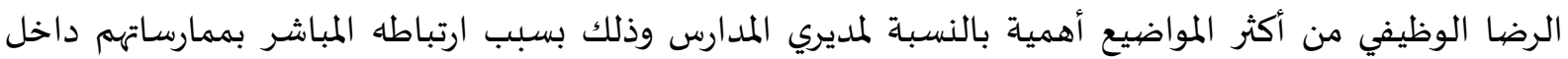
المؤسسة وخارجها (الخضري وسلامة 1982م).

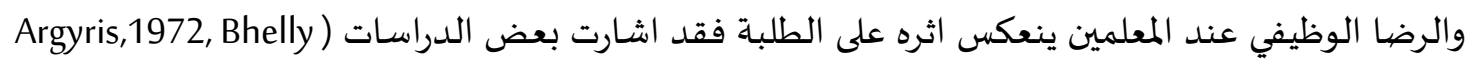
، 1982)،

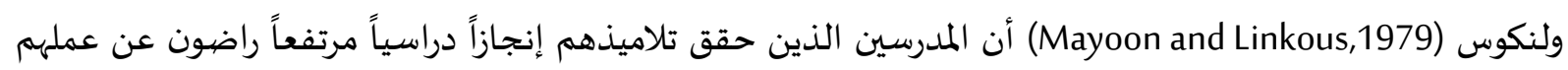

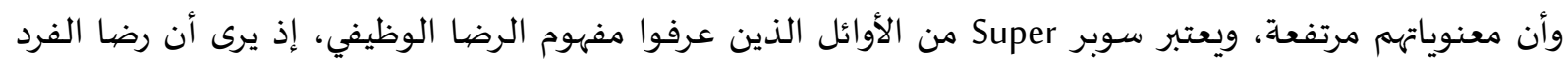

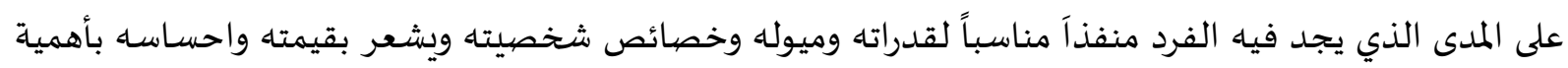

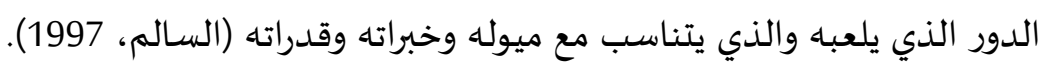

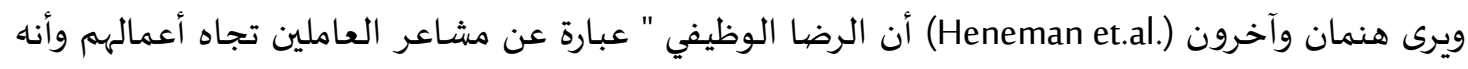

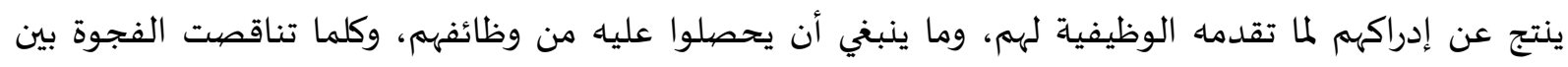
الإدراكين كلما ارتفع الرضا الوظيفي لدى العاملين.

ودراسة الرضا الوظيفي تتدرج تحت عدد من المدارس الفكرية المختلفة:

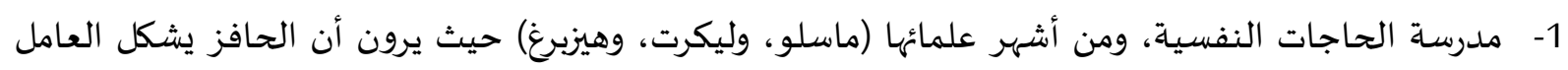

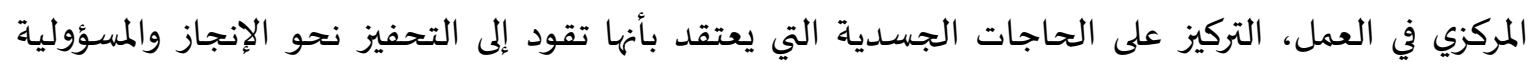

والمكانة.

2- المدرسة الثانية اهتمت بالقيادة كعامل رئيسي في الرضا عن العمل، إذ يرى بعض علمائها مثل

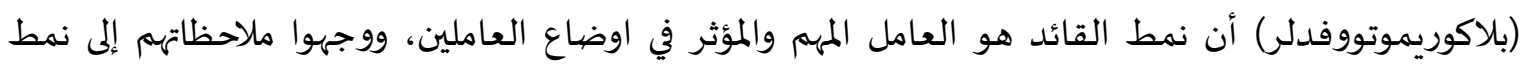
القيادة واستجابة المرؤوسين. 3- أما المدرسة الثالثة فقد بدأت في مانشيستر من قبل (لابتون، جولر، وليج) حيث وضعوا مدخلاً جديداً للرضا عن العمل ينطلق من زوايا متعددة ويركز على الجهد والمكافأة كمتفير منهم.

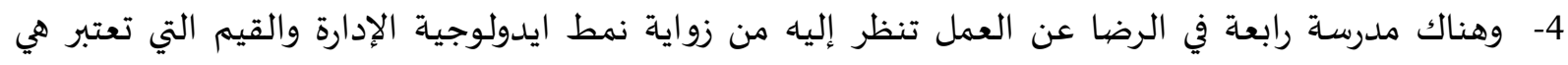

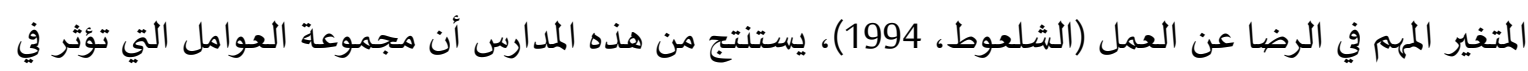


مستوى الرضا الوظيفي للعاملين، يمكن اجمالها فيما يلي: العمل نفسـه وظروفه، والعلاقات مع زملاء العمل،

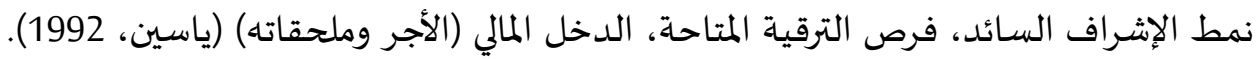

\section{ومن أهم النظريات ذات الصلة بالرضيا الوظيفي:} اولاً: نظرية ماسلو للحاجات: إذ قدم ماسلو(A.H. Maslow) هرماً للحاجات يتكون التهات من خمسة مستويات وهي الحاجة لتحقيق الذات، والحاجة إلى تقدير الذات، والحاجة للانتماء والحب، والحاجة للأمن والطمأنينة، والحاجات الأساسية والفسيولوجية، معتبراً أن اشباع هذه الحاجات يحقق الرضا لتدا الوظيفي للفرد وبالتالي إنتاجيته

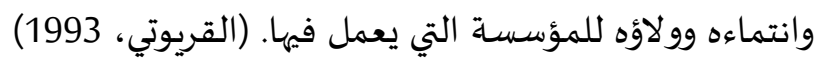

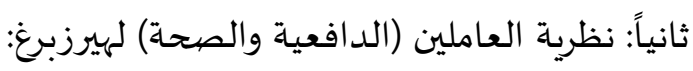
تقوم هذه النظرية على مجموعتين من العوامل:

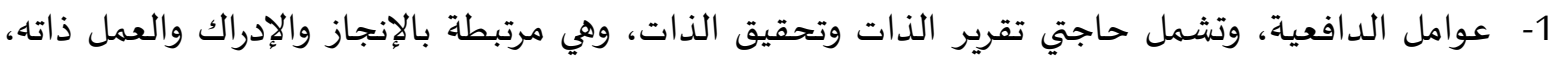

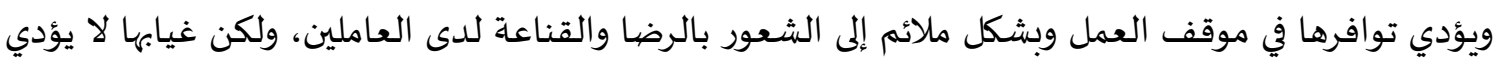
بالضرورة إلى شعور بالالتزام (الطويل، 1998). 2- عوامل الصحة وتشتمل على الحاجات الدنيا الثلاث التابعة لماسلو وهي السلامة والأمن والاندماج الاجتماعي

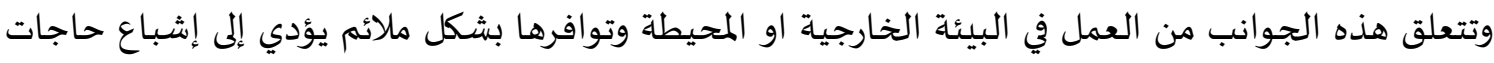

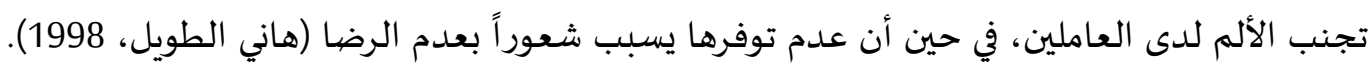

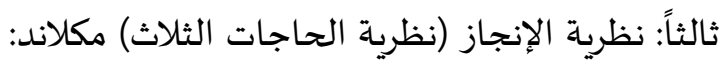
يرى ميكلاند (David Mcclelland) هذه النظرية بإن العمل في المنظمة يوفر فرصاتة لإشباع الإنساع حاجات ثلاث هي:

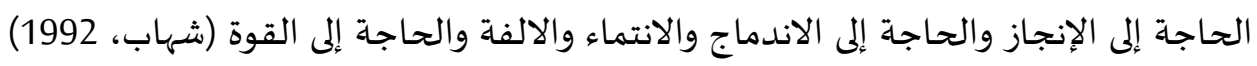

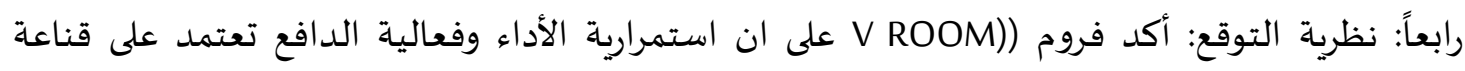

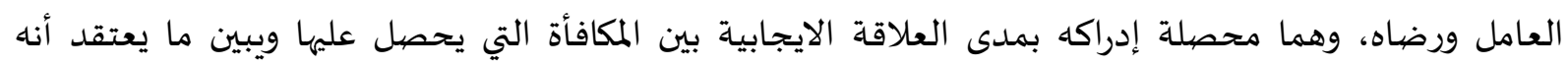
يستحق. خامساً: نظرية ماري جينزل: وقد بينت النظرية أن أهم عوامل الرضا الوظيفي هو التطور والتقدم في العمل، ومتعة العمل والخبرة الطويلة (Genzel, 1998).

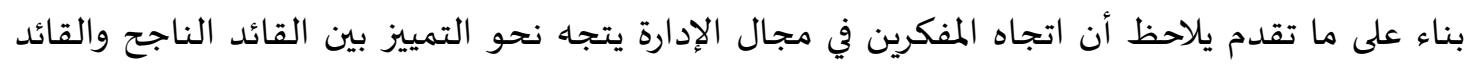

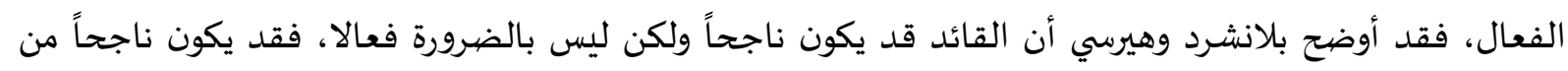

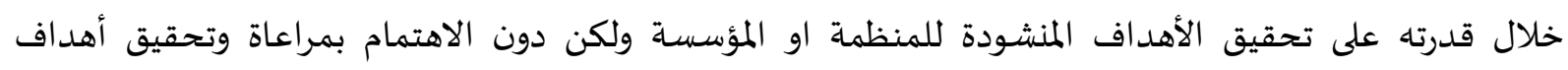

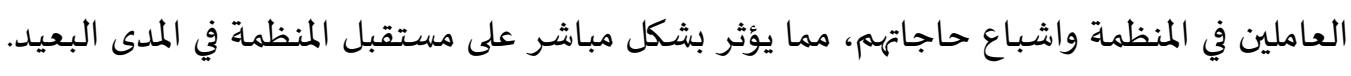

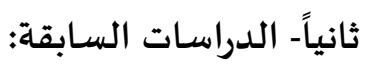

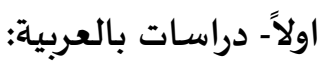

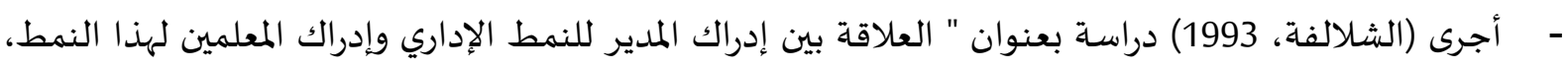
وأثر هذه العلاقة على مستوى الروح المعنوية لدى المعلمين في المدارس الثانوية الحكومية في منطقتي لواء ماركا

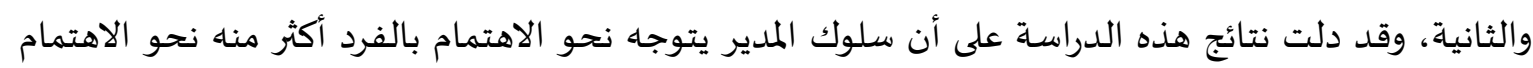


بالنظام الرسمي، كما دلت على وجود فروق ذات أثر دال إحصائياً على بعدي السلوك الإداري بين إدراك

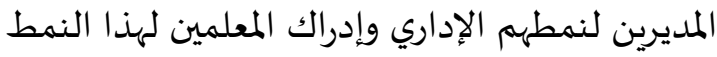
- أجرى (السيد، 2017). دراسة بعنوان الأنماط الإدارية لمديري المدارس وعلاقتها بالرضا الوظيفي لدى المعلمين

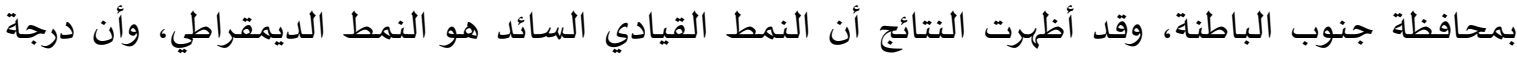
الرضا الوظيفي العام لمعلمي محافظة جنوب الباطنة كانت مرتفعة. أجرت (درويش، 2017). دراسة هدفت الى تعرف الأنماط القيادية السائدة لدى مديري التعليم الثانوي وعلاقتها

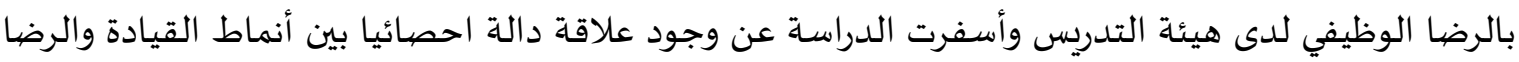
الوظيفي لدى الأساتذة بالتعليم الثانوي. اجرت (الأشقر، 1994) دراسة بعنوان الانماط الإدارية السائدة في جامعتي اليرموك والعلوم والتكنولوجيا كما

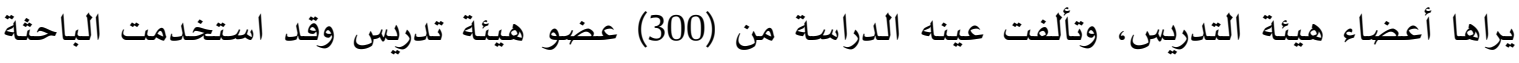

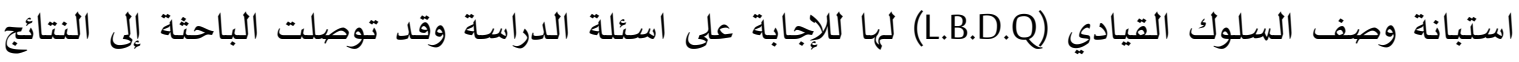

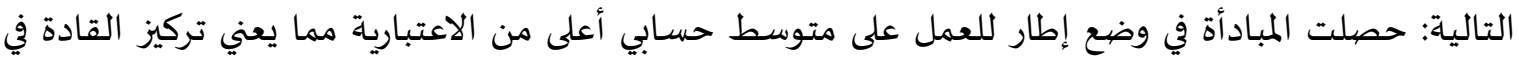

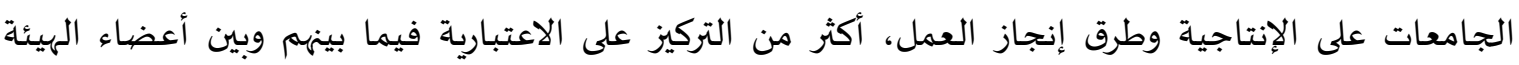

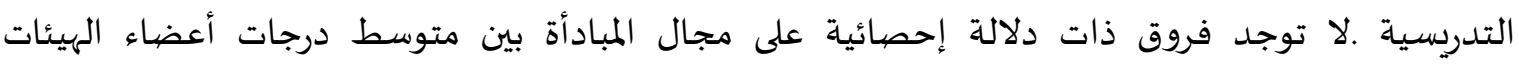

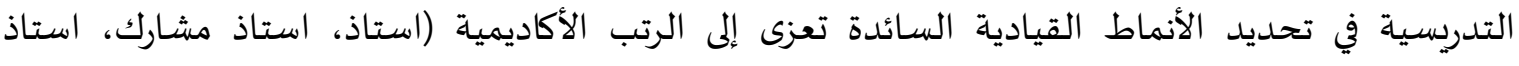

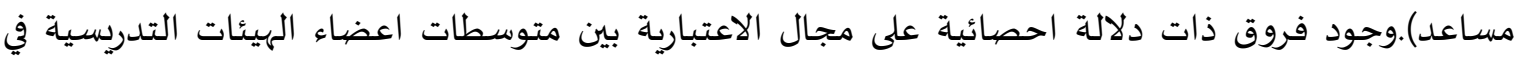

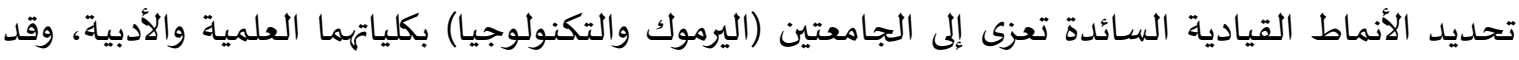
كانت هذه الفروق لصالح جامعية اليرموك. كما أجرى (زكريان، 1994). دراسـة هدفت إلى معرفة الأنماط الإدارية وعلاقتها بدرجة تطبيق الأسس النظرية

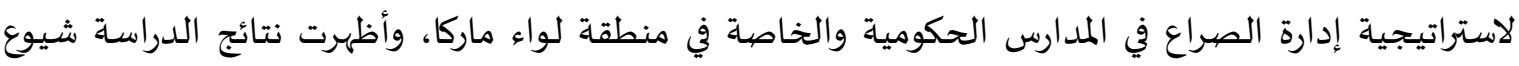

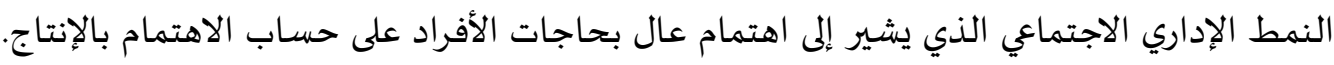

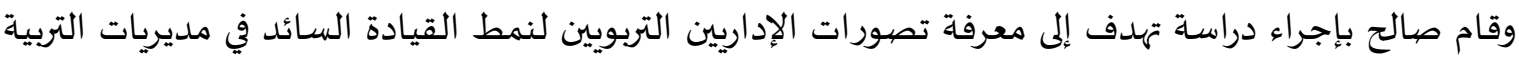
والتعليم في محافظة إربد، من خلال تناول أربعة أنماط قيادية هي (الإداري التقليدي، الإداري الاجتماعداعي،

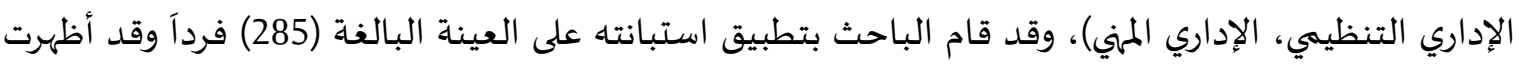

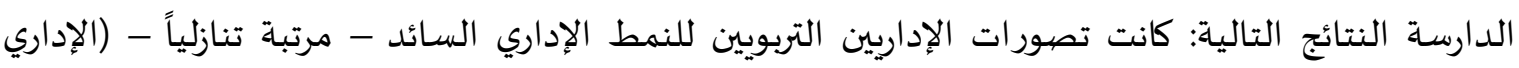

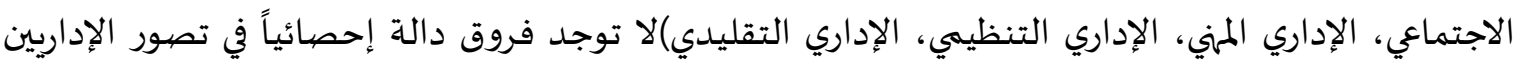

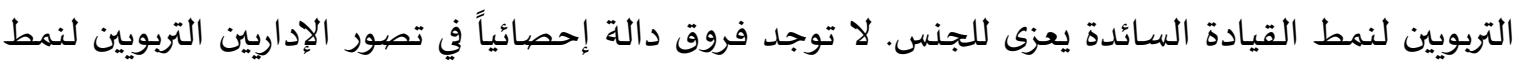

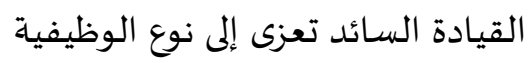

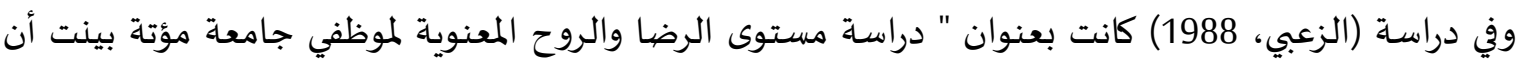

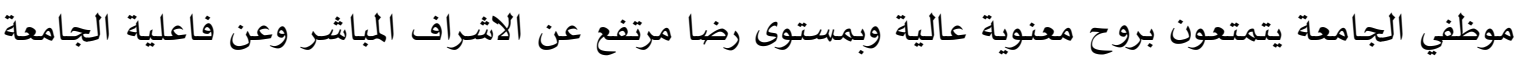
وعن أعمالهم وعن علاقتهم بزملاء العمل وعن ظروف الجاهمه يتمتون بروحالهم المادية وعن اهمية اعمالهم الاجتماعية بينما

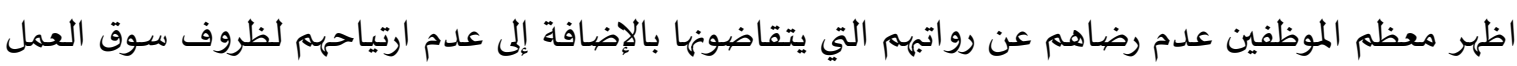
الحالية والتي تنعكس على استقرار أعمالهم.

وفي دراسة إجراها (طناش، 1990) للتعرف على مستوى الرضا الوظيفي لأعضاء الهيئة التدريسية في الجامعة التهائ

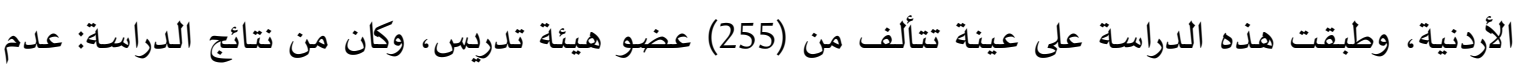


وجود فروق ذات دلالة احصائية في مستوى الرضا الوظيفي تعزى للجنس او الحالة الاجتماعية، بينما وجدت

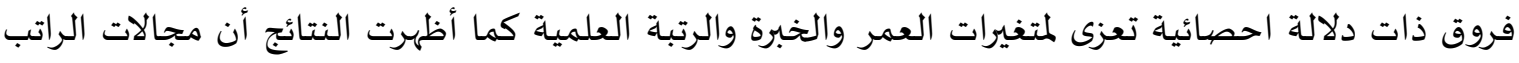

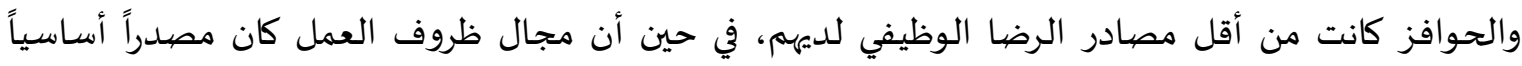

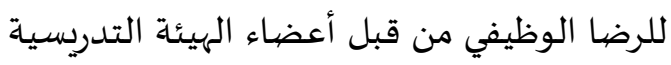
وفي دراسة قام بها (ناجي، 1993). هدفت إلى دراسة الرضا الوظيفي لدى المعلمين والمعلمات في التعليم العام

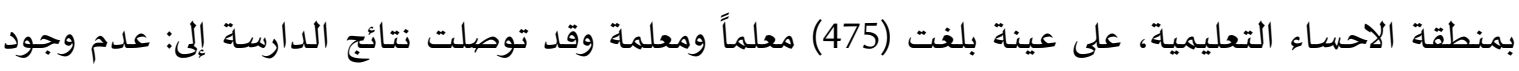

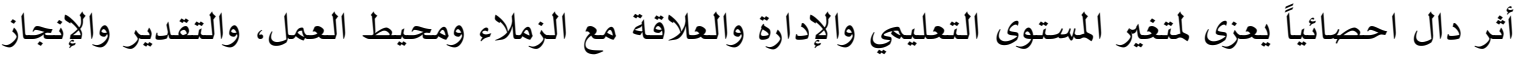

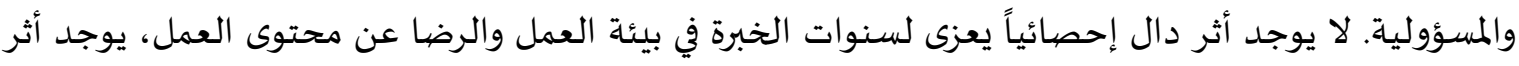

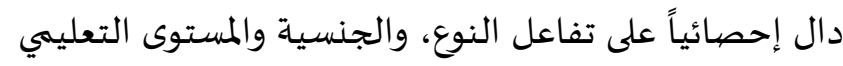
وقام (الحوراني، 1984) بدارسة هدفت تعرف (تأثير النمط القيادي للمدير وضبط الوضيع المدرسي على كل من

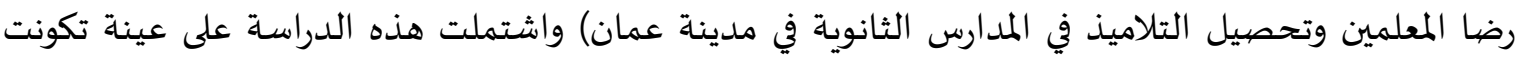

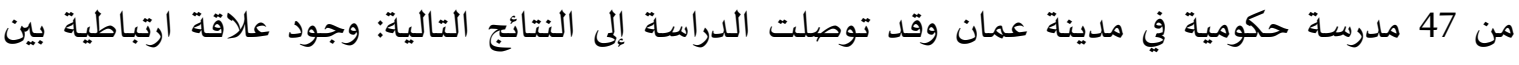

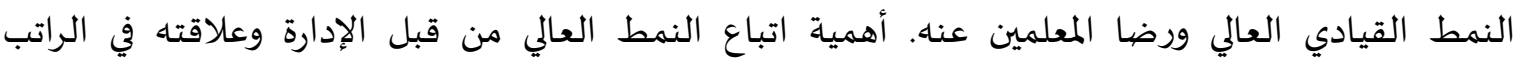

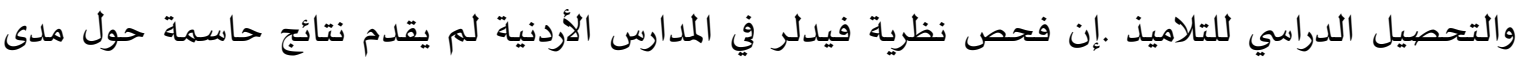
صحة النظرية كما اعتقد الباحث. وقد أجرى (بني ارشيد، 1991). دراسة هدفت إلى معرفة أثر الدور القيادي لمديري التربية والتعليم في الأردن في

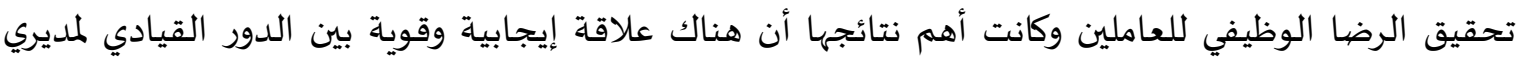

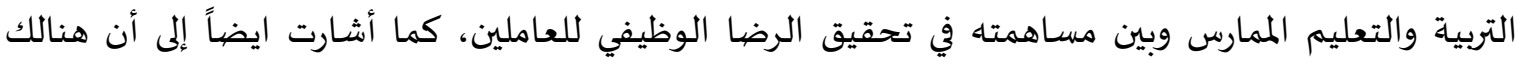
علاقة إيجابية بين كل جانب من جوانب الدور القيادي الممارس وبين مساهمة كل منها في تحقيق الرضا الوظيفي

للعاملين

ثانياً: الدراسـات الأجنبية: - وقد أجرى بالمر (Palmar, 1995) دراسة هدفت تعرف العلاقة بين الأنماط الإدارية والفعالية المدرسية، وقد

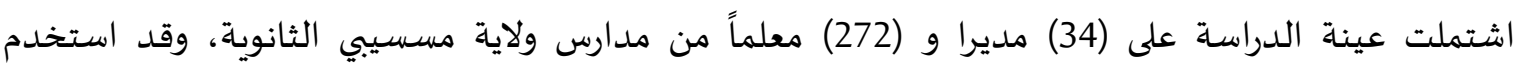

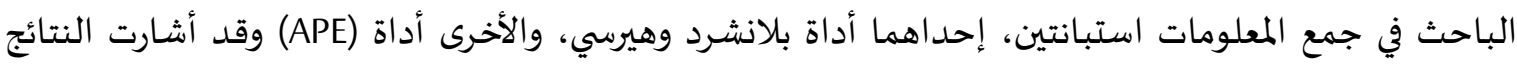

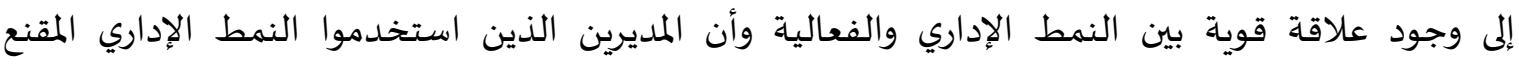

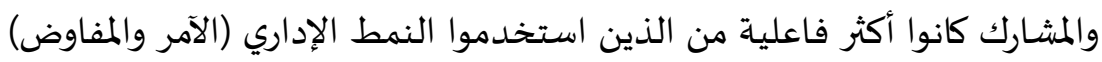

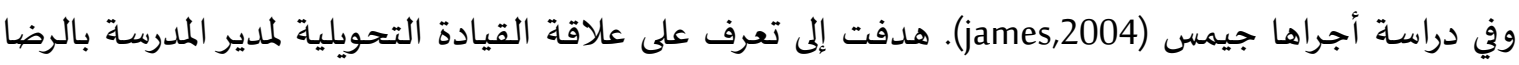
الوظيفي للمعلمين، توصلت الدراسة وجود اثر للنمط القيادي التحويلي على رضا المعلمين، وتطور إنجازات

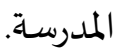
وفي دراسة أجراها كروكماز على المدارس الثانوية في تركيا حول أثر الانماط القيادية لمديري المدارس الثانوية في

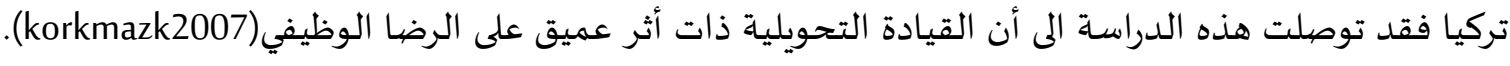
أما دراسـة هيوز (Hughes, 1996). التي هدفت تعرف الأنماط القيادية لدى مديري ومديرات المدارس الثانوية في

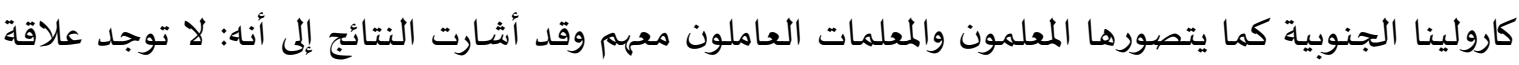


دالة إحصائياً بين تصورات المعلمين للنمط القيادي لمدير المدرسة وجنس المعلمين وجنس المدير. لا توجد فروق دالة إحصائياً بين مديري المدارس الثانوية ومديرات المدارس الثانوية في النمط المعادين القيادي.

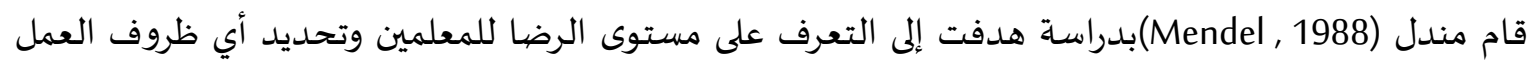

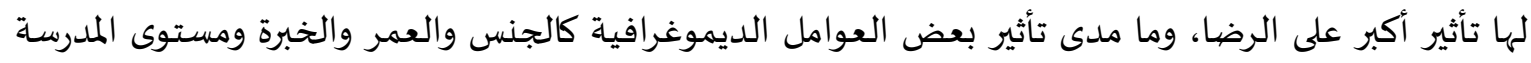

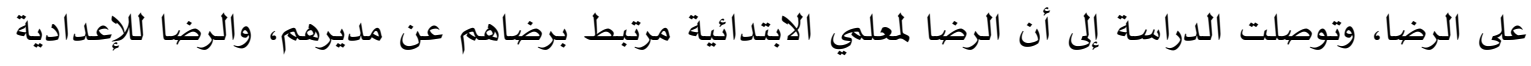

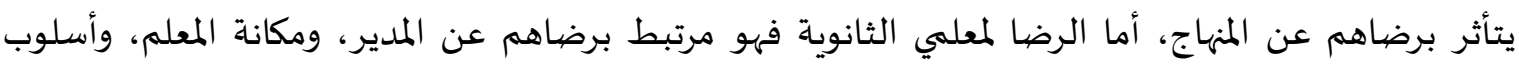
العمل والعلاقات الإنسانية.

كام قام كولير (Collier) بدراسة هدفت الكشف عن متنبآت الرضا الوظيفي للمعلمات في المدارس الإبتدائية،

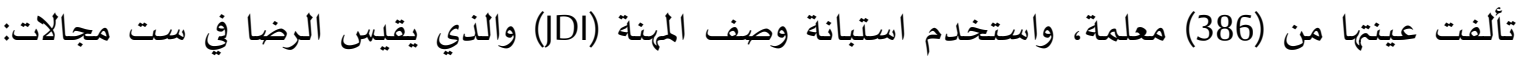

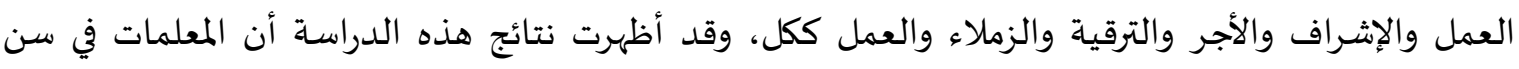

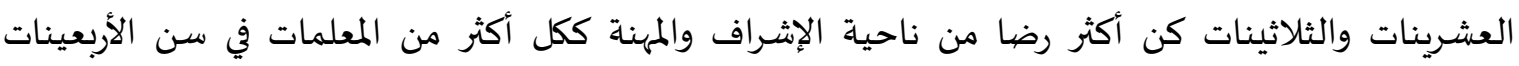

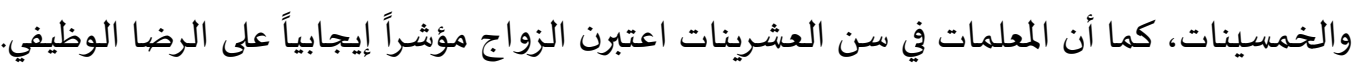

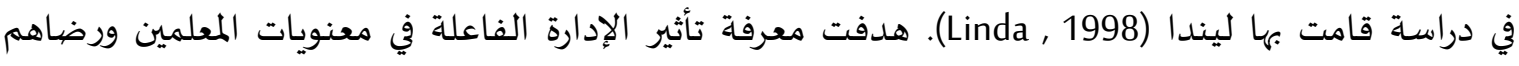

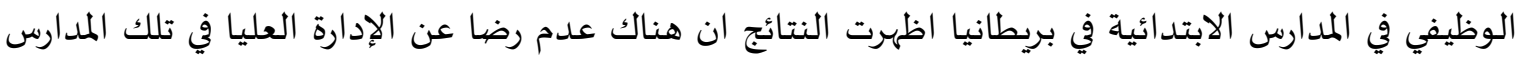
وكان السبب الرئيسي في عدم الرضا في مجال قلة الاحترام

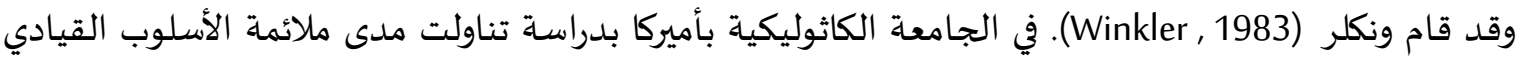

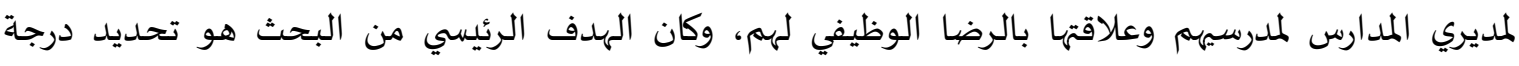

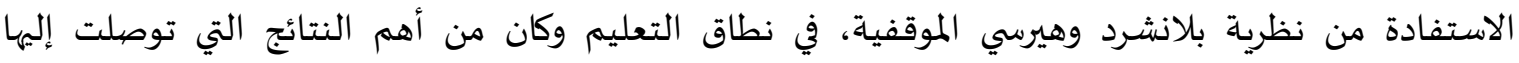

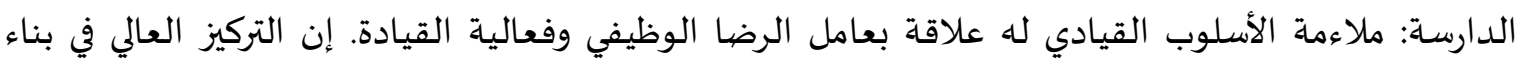

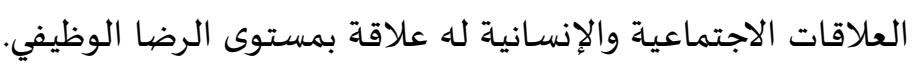
كما أجرى متشيل (Mitchell, 1989). دراسة هدفت التعرف إلى العلاقة بين الرضا الوظيفي للمعلم، والنمط المطائه

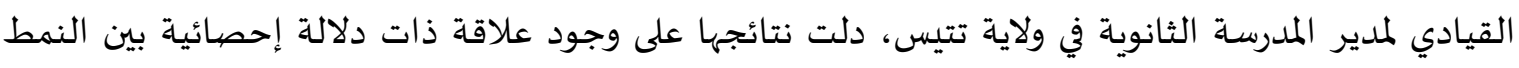
القيادي للمدير والرضا الوظيفي للمعلم. وقد قام هنري (Henry, 1989). بدراسة هدفت إلى التعرف أنماط القيادة لدى المديرين والرضيا الوظيفي للمعلم

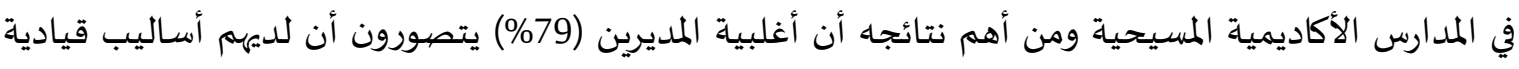

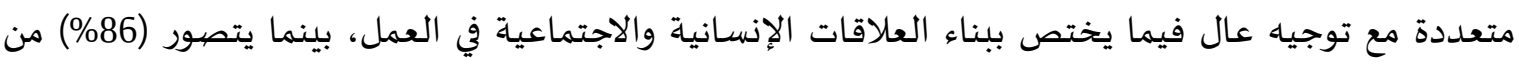

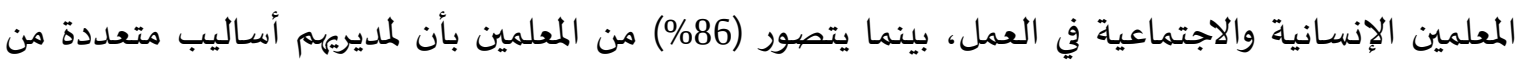

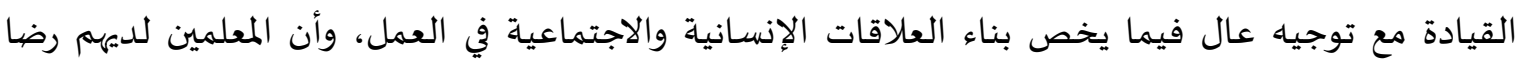
بدرجة كبيرة عن نمط قيادة مديريهم. كما قام سكمسكي (Secumski, 1993) بدراسة هدفت فحص العلاقة بين الرضا الوظيفي لمعلمي المدارس الابتدائية وأساليب المديرين الإدارية وتحصيل الطلبة، باستخدام عينة تتألف من (23) مدير مدرسة ابتدائية و

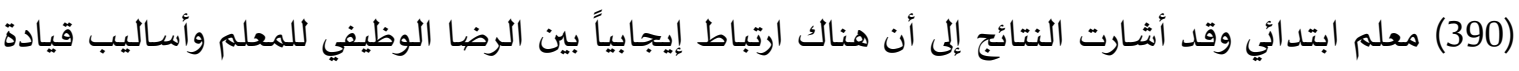
المديرين الذين يعملون كقادة فعالين. 
التعقيب على الدراسات السـابقة:

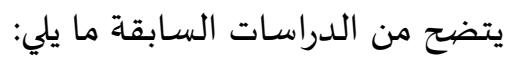

1- أهمية القيادة في تحقيق أهداف العاملين ورفع درجة الرضا الوظيفي لديهم وبالتالي تحقيق أهداف المؤسسة

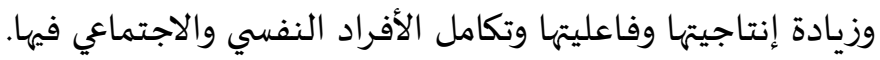

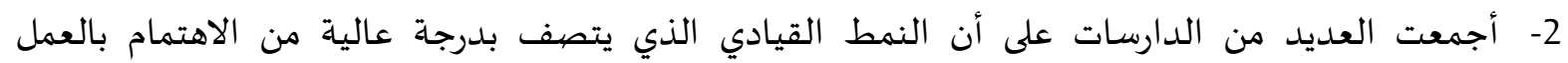

والعاملين هو الأكثر تحقيق للرضا الوظيفي للعاملين في المؤسسة (Perkins, 1992, Lamb, 1993).

3- أثبتت الدارسات أهمية النمط القيادي الذي يؤثر في طبيعة العلاقات بين القائد والعاملين معه ويؤثر في

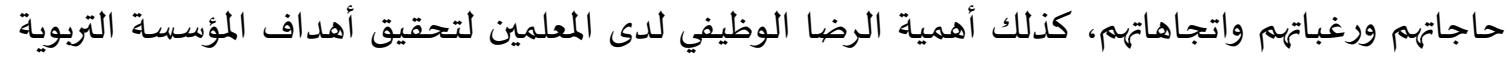
وقد اختلفت الدراسات في الأهداف تبعاً لأهداف الباحثين فمنها ما أكدت على تصنيف الهيه السلوك القيادي ومنها

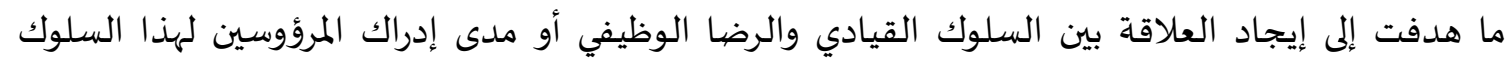

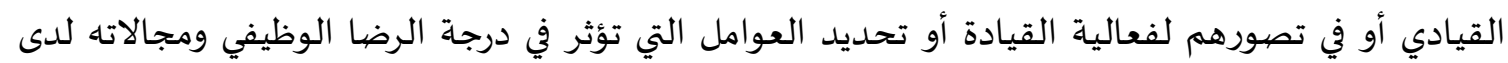

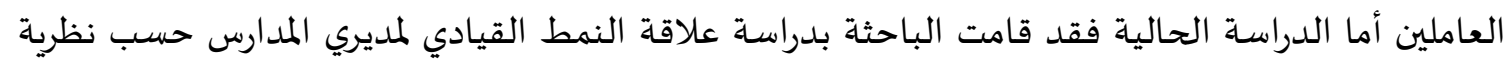

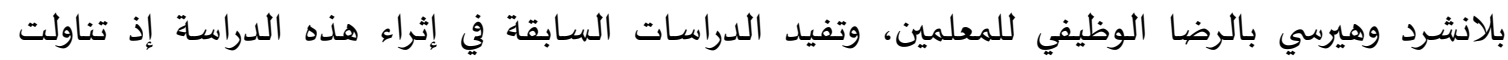

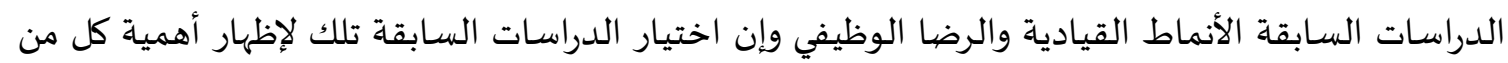

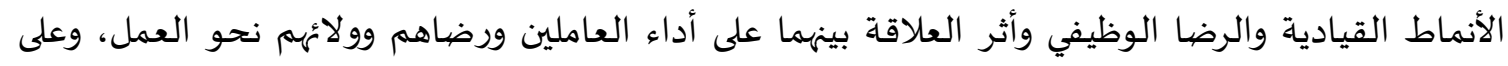

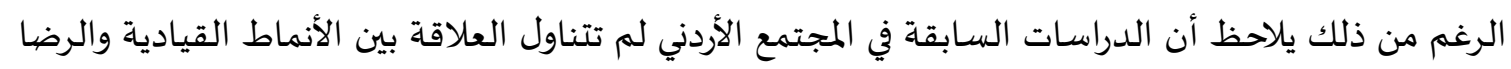

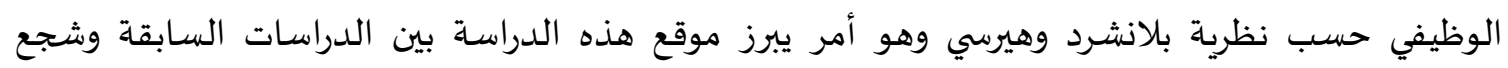
الباحثة على تحديد تلك العلاقة مشكلة بحثية ودراستها

3- منهجية الدراسـة وإجراءاتها

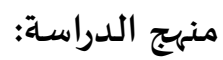

استخدمت الدراسة المنهج الوصفي المستي؛ كونه الأنسب لهذه الدراسة.

مجتمع الدراسة:

يتكون مجتمع الدراسة من جميع مديري ومعلمي المرحلة الثانوية في منطقة لواء ماركا للعام الدراسي

2021/2020

إذ بلغ عدد المديرين (77) مدير ومديرة، وعدد المعلمين (1534) معلم ومعلمة. كما يبينه الجدول التالي

جدول رقم (1) توزع أفراد مجتمع الدراسة من مديرين ومعلمين

\begin{tabular}{|c|c|c|c|}
\hline المجمبوع & انثى & ذكر & \\
\hline 77 & 45 & 32 & المديرون \\
\hline 1534 & 832 & 702 & المعلمون \\
\hline
\end{tabular}

عينة الدراسـة:

1- تم اختيار 40 مديرة، من أصل 45 مديرة واختيار 29 مديراً من أصل 32 مديراً وذلك بالطريقة العشوائية. 
2- يتم اختيار عينة من المعلمين والمعلمات من منطقة لواء ماركا إذ تم اختيار أربعة أفراد من معلمين لكل مدير ومديرة إذ تم اختيارهم لغاية الدراسة بطريقة عشوائية بلغ عددهم (275) معلم ومعلمة

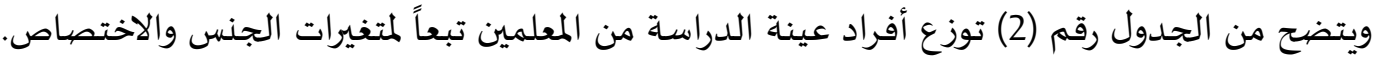

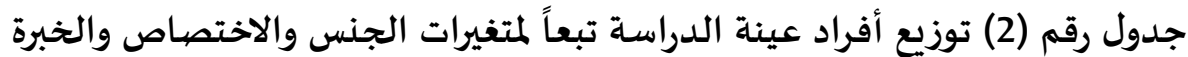

\begin{tabular}{|c|c|c|c|}
\hline \multicolumn{2}{|c|}{ الاختصهاص } & \multicolumn{2}{|c|}{ الجنس } \\
\hline 127 & علمي & 115 & ذكر \\
\hline 148 & ادبي & 160 & أنثى \\
\hline 275 & المجموع & 275 & لمجموئ \\
\hline
\end{tabular}

ادوات الدراسـة:

استخدمت الباحثة في هذه الدراسـة الأدوات التالية:

1- أداة وصف فاعلية وتكيف القائد Description Leader Effectivencss And Adaptabilityالخاصة بالأساليب فلادوان القيادية للمديرين، وهذه الأداة تم تصميمها من قبل بلانشرد وهيرسي (Blanchard, Hersey) في مركز الدراسات

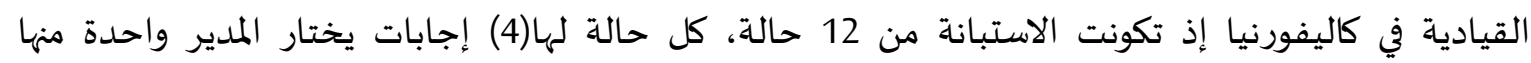

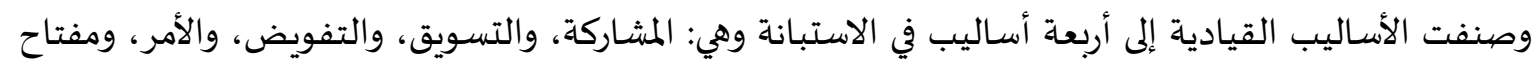

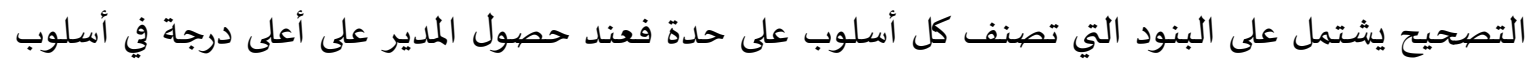

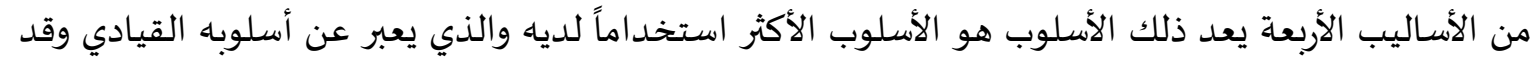

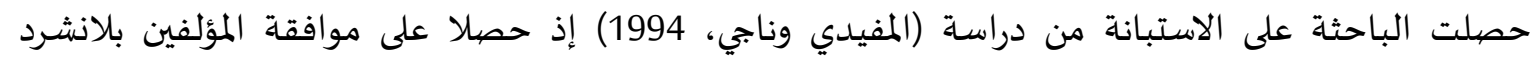

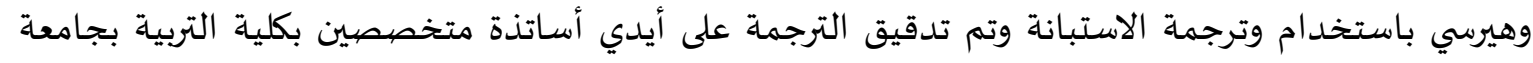
الملك فيصل وتوصل الباحثان إلى صدق الأداة عن طريق عرضها على محكمين وقد تم التوصل إلى ثبات الأداة

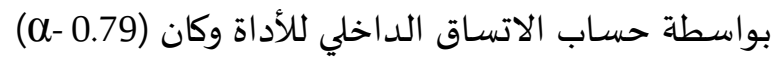

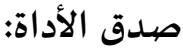

إضافة إلى ذلك قامت الباحثة باستخراج الصدق المنطقي للأداة بعرضها على عشرة محكمين مختصين في التربية وعلم النفس في كلية العلوم التربوية إذ طلب من كل منهم بيان مدى مناسبة كل فقرة من فقرات التهات الأداة

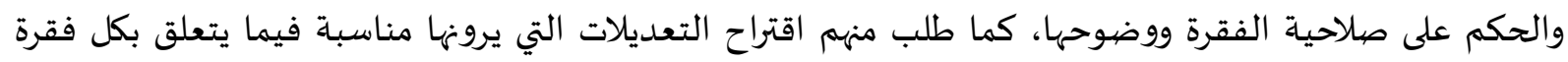

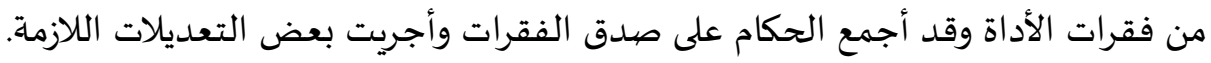
ثبات الأداة: تم استخراج الثبات بواسطة حساب معامل الاتساق الداخلي الدافلي للاختبار على عينة الدراسة الحالية بواسطة كرونباخ الفا وكان (a-0.67).

ثانياً استبانة الرضيا الوظيفي:

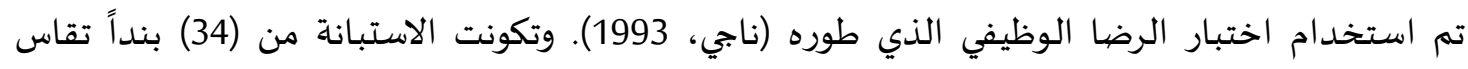

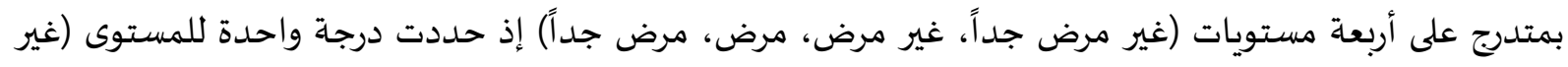

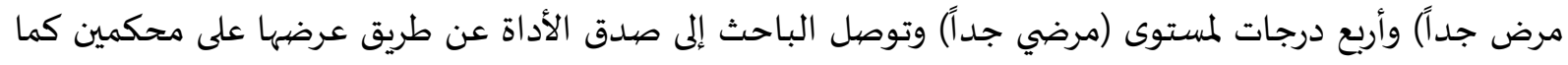
توصل إلى ثبات الأداة بواسطة دساب اتمات الاتساق الداخلي للأداة وكان (a- a.89). 


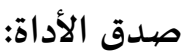

إضافة إلى ما تقدم قامت الباحثة باستخراج الصدق المنطقي للأداة بعرضها على عشرة محكمين مختصين في التربية وعلم النفس في كلية العلوم التربوية إذ طلب من كل منهم تحديد مدى مناسبة كل فقرة من فقرات الأداة

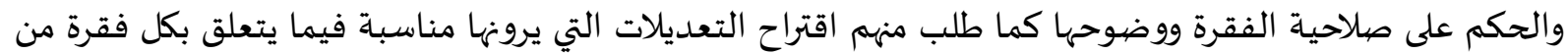

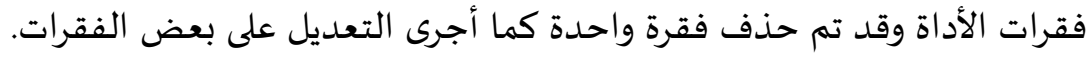

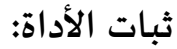

تم استخراج الثبات بواسطة حساب معامل الاتساق الداخلي للاختبار على عينة الدراسة الحالية بواسطة كرونباخ (الفا) وكان (a-0.92) وهو ذو دلالة.

إجراءات الدراسة:

لتحقيق اهداف الدارسة وبيان الفروق في الرضا الوظيفي لدى المعلمين تبعاً للنمط القيادي للمدير وتبعا

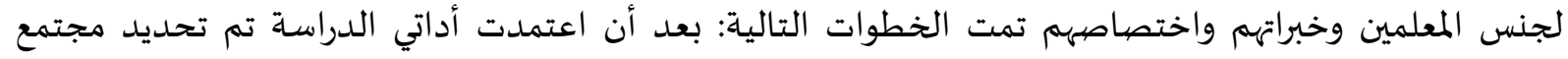
الدراسة وتحديد العينة الفعلية التي ستجري عليها الدراسة. قامت الباحثة بتطبيق أداتي الدراسـة على عينة الدراسـة

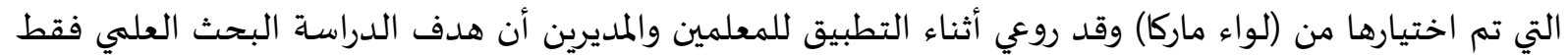

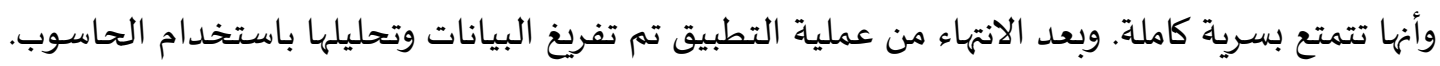

المعالجة الاحصيائية:

هدفت الدراسة الحالية بيان فيما إذا كانت توجد علاقة في الرضا الوظيفي لدى المعلمين تعزى لجنس واختصاص المعلم ونمط المدير القيادي والتفاعل بينهما. وقد تم استخدام تحليل التباين الثنائي لبيان فيما إذا كان لمعان هناك فروق ذات دلالة احصائية في الرضا الوظيفي للمعلمين يعزى لمتغير جنس واختصاص المعلم ونمط المدير وفير القيادي والتفاعل بينهما.

4- نتائج الدراسـة ومناقشتها

إجابة السؤال الأول: ما أنماط القيادة لدى مديري المدارس الثانوية حسب نظرية بلانشرد وهيرسي؟

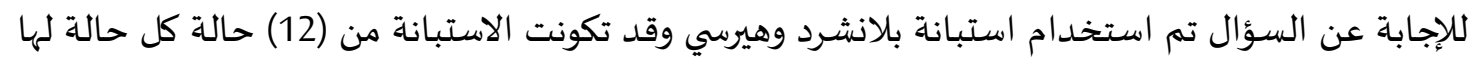
(4) اجابات يختار المدير واحدة منها وصنفت الأساليب إلى أربعة أساليب وهي: التشاركي والتسويقي والتفويضي

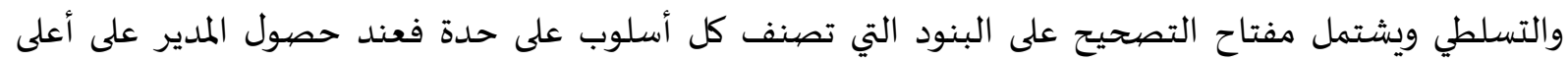

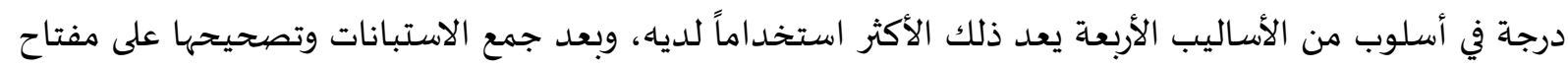

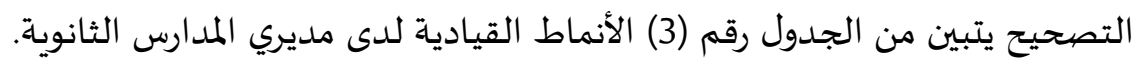

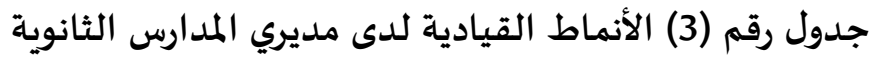

\begin{tabular}{|c|c|c|}
\hline عدد معلمي النمط & عدد المديرين & النمط القيادي \\
\hline 80 & 20 & التسلطي \\
\hline 92 & 23 & التسويقي \\
\hline 83 & 21 & التشاركي \\
\hline
\end{tabular}


المجلة العربية للعلوم ونثر الأبحاث ـ مجلة العلوم التربوية والنفسية ـ المجلد الخامس ـ العلد الرابع والأربعون ـ نوفمبر 2021م

\begin{tabular}{|c|c|c|}
\hline عدد معلمي النمط & عدد المديرين & النمط القيادي \\
\hline 20 & 5 & التفويضي \\
\hline 275 & 69 & المجموع \\
\hline
\end{tabular}

يتبين من الجدول رقم (3) أن النمط التسويقي هو النمط الأكثر شيوعاً لدى عينة الدراسـة من مديري المدارس الثانوية يليه النمط التشاركي ثم النمط التسلطي ثم النمط التفويضي والذي حصول حصل على رقئ رقم قليل مقارنة

بالأنماط القيادية السابقة.

إجابة السؤال الثاني: ما درجة الرضا الوظيفي لدى المعلمين؟

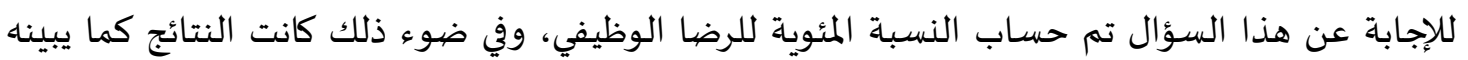

الجدول رقم (4) (2) (2) (2)

جدول رقم (4) النسبة المئوية للرضا الوظيفي لدى المعلمين

\begin{tabular}{|c|c|c|c|}
\hline \multicolumn{2}{|c|}{ الاختصباص } & \multicolumn{2}{|c|}{ الجنس } \\
\hline 0.583 & علمي & \multirow{2}{*}{0.585} & \multirow{2}{*}{ ذكور } \\
\hline 0.56 & أدبي & & \\
\hline 0.635 & علمي & \multirow{2}{*}{0.628} & \multirow{2}{*}{ إناث } \\
\hline 0.627 & ادبي & & \\
\hline
\end{tabular}

إجابة السؤال الثالث: هل توجد فروق ذات دلالة إحصائية في الرضا الوظيفي لدى المعلمين تعزى لجنس

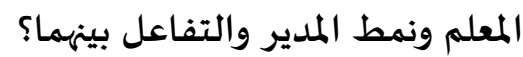

للإجابة عن هذا السؤال تم استخدام تحليل التباين الثنائي كما هو مبين في الجدول رقماعم (5).

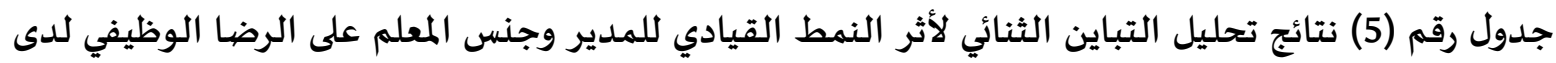
المعلمين

\begin{tabular}{|c|c|c|c|c|c|}
\hline مستوى الدلالة & قيمة ف & متوسط متجموع & درجات الحرية & المربعات & مصدر التباين \\
\hline 0.000 & 17.398 & 1.897 & 1 & 1.897 & ا- جنس المعلم \\
\hline 0.000 & 34.581 & 3.771 & 3 & 11.313 & ب- النمط القيادي \\
\hline 0.529 & 0.739 & 8.063 & 3 & 0.242 & \multirow{4}{*}{ جـ- التفاعل بين جنس والنمط القيادي } \\
\hline \multirow[t]{3}{*}{0.000} & 14.623 & 1.922 & 7 & 13.452 & \\
\hline & & 0.109 & 267 & 29.115 & \\
\hline & & 0.155 & 574 & 42.567 & \\
\hline
\end{tabular}

يبين الجدول رقم (5) وجود فروق ذات دلالة إحصائية تعزى لعامل الجنس كما يبين الجدول نفسه وجود

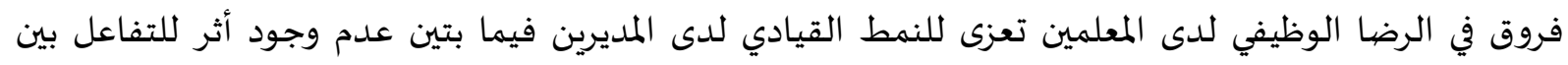

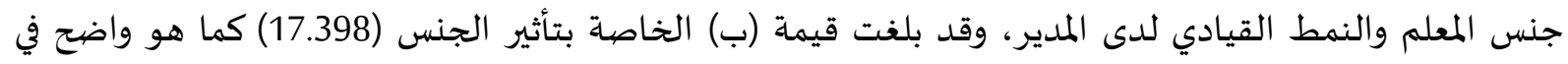

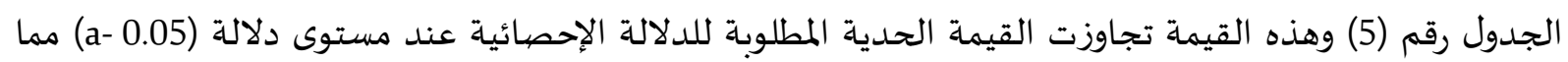


يشير إلى وجود فروق ذات دلالة، وبالمقارنة بين متوسط الرضا الوظيفي لدى الذكور والإناث نجد أن الرضا الوظيفي لدى الإناث أعلى منه لدى الذكور كما هو مبين في الجدول رقم (6). جدول رقم (6) متوسط الرضيا الوظيفي لدى المعلمين

\begin{tabular}{|c|c|c|}
\hline المتوسط & عدد الحالات & الجنس \\
\hline 2.34 & 115 & ذكر \\
\hline 2.51 & 160 & انثى \\
\hline
\end{tabular}

يبين الجدول رقم (6) أن متوسط الرضا الوظيفي لدى الإناث (2.51) بينما كان لدى الذكور (2.34) أما فيما

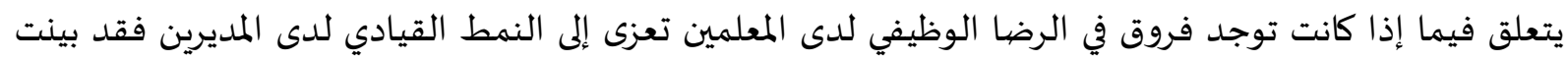

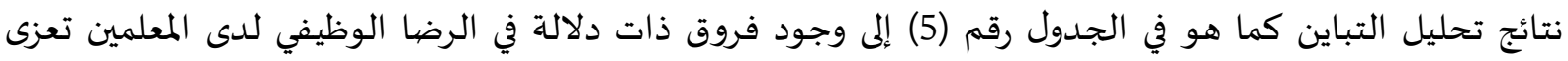

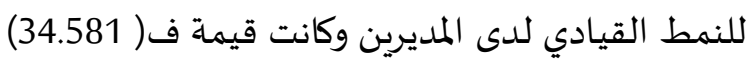

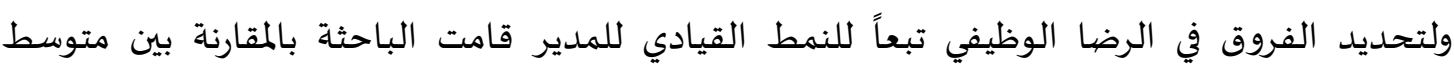

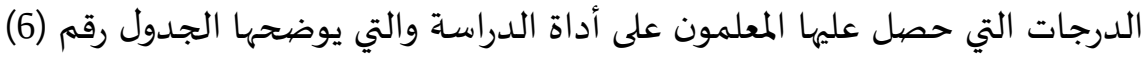

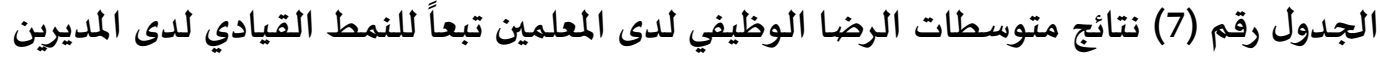

\begin{tabular}{|c|c|c|}
\hline متوسط الرضيا الوظيفي & عدد المعلمين & النمط القيادي \\
\hline 2.13 & 80 & 1 \\
\hline 2.65 & 92 & 2 \\
\hline 2.52 & 83 & 3 \\
\hline 2.31 & 20 & 4 \\
\hline & 275 & المجموع \\
\hline
\end{tabular}

وقد تم استخدام اختبار شيفية لمعرفة الفروق في الرضا الوظيفي تبعاً للنمط كما هو موضح في الجدول

جدول رقم (8) نتائج اختبار شيفيه لتحديد الفروق في الرضا الوظيفي بين المعلمين تبعاً للنمط القيادي لدى المديرين

\begin{tabular}{|c|c|c|c|c|}
\hline مستوى الدلالة & الانحراف المعياري & الفروق بين المتوسطات & النمط القيادي & النمط القيادي \\
\hline 0.000 & 0.051 & 50.5219 & 2 & \multirow{3}{*}{ التسلطي } \\
\hline 0.000 & 0.052 & 50.3914 & 3 & \\
\hline 0.203 & 0.083 & 0.187 & 4 & \\
\hline 0.000 & 0.051 & 50.5219 & 1 & \multirow{3}{*}{ التسويقي } \\
\hline 0.083 & 0.050 & 0.1305 & 3 & \\
\hline 0.001 & 0.82 & 50.3432 & 4 & \\
\hline 0.000 & 0.051 & 50.3914 & 1 & \multirow{3}{*}{ التشاركي } \\
\hline 0.830 & 0.050 & 0.1305 & 2 & \\
\hline 0.088 & 0.83 & 0.2127 & 4 & \\
\hline 0.203 & 0.083 & 0.1787 & 1 & \multirow{3}{*}{ التفويضي } \\
\hline 0.001 & 0.082 & 50.3432 & 2 & \\
\hline 0.088 & 0.083 & 0.2127 & 3 & \\
\hline
\end{tabular}


من خلال المقارنات الثنائية التي أجريت أظهرت نتائج اختبار شيفيه أن هناك فرقاً ذا دلالة احصائية في الرضا الوظيفي لدى المعلمين بين النمط التسلطي لدى المديرين والنمط التسويقي إذ بلغ قيمة الفرق (- 5219 *)

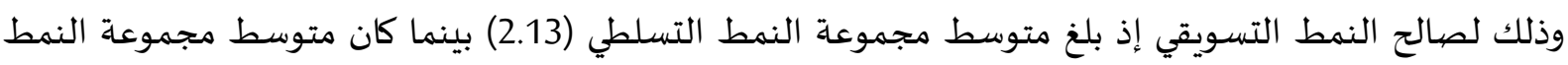

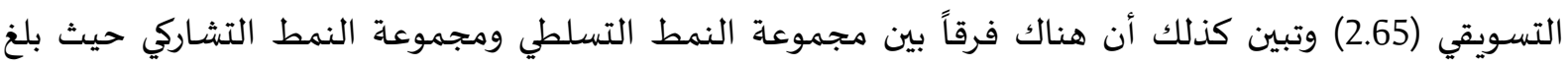
قيمة الفرق (- 0.3914) وذلك لصالح النمط التشاركي إذ بلغ متوسط مجموعة النمط التشاركي (2.52) في حين كان

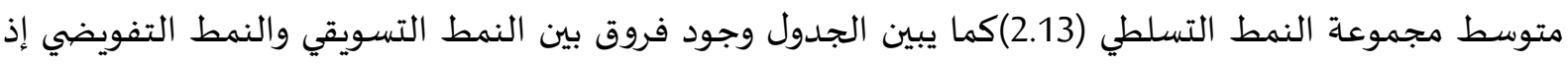
بلغ الفرق(0.3432) وذلك لصالح النمط التسويقي حيث بلغ متوسط مجموعة النمط التسويقي(2.65) في حين كان متوسط مجموعة النمط التفويضي(2.31) ولم يظهر الجدول فروق ذات دلالة إحصائية في المقارنات التي أجريت بين النمطين التسويقي والتشاركي وكذلك النمطين التسلطي والتفويضي، وكذلك بين النمطين التفويضي والتشاركي.

إجابة السؤال الرابع: هل توجد فروق ذات دلالة إحصائية في الرضا الوظيفي لدى المعلمين تعزى المئي لاختصاص المعلم ونمط المدير القيادي والتفاعل بينهما؟ لوله

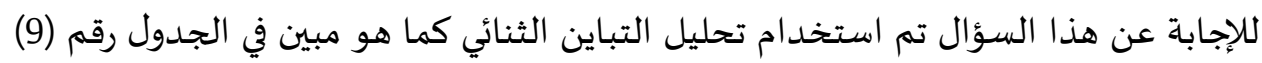
جدول رقم (9) نتائج تحليل التباين الثنائي لأثر النمط القيادي للمدير واختصاص التحاصئ المعلم على الرضا الوظيفي لدى المعلمين

\begin{tabular}{|c|c|c|c|c|c|}
\hline 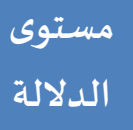 & قيمة & متوسط مجموع & 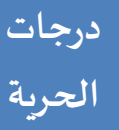 & 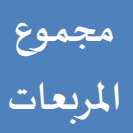 & مصيادر التباين \\
\hline 0.354 & 0.862 & 9.595 & 1 & 9.595 & اختصاص المعلم \\
\hline 50.000 & 38.079 & 4.237 & 3 & 12.710 & النمط القيادي لدى المدير \\
\hline 0.923 & 0.160 & 1.781 & 3 & 5.344 & التفاعل بين اختصاص المعلم والنمط القيادي \\
\hline
\end{tabular}

يبين الجدول رقم (9) عدم وجود فروق في الرضا الوظيفي تعزى لعامل الاختصاص، كما يبين الجدول رقم

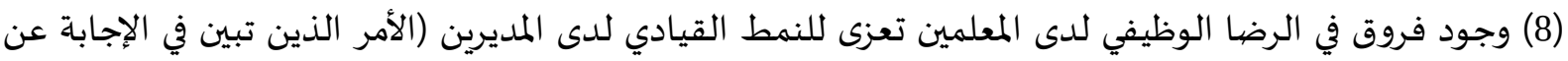

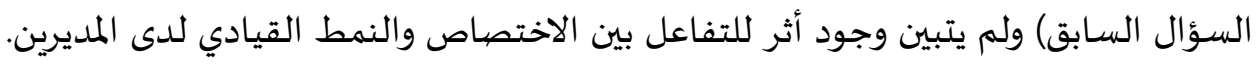

مناقشـة النتائج: هدفت الدراسـة تعرف فيما إذا كانت هناك فروق في الرضا الوظيفي لدى المعلمين تعزى لجنس واختصياص المعلم ونمط المدير القيادي والتفاعل بينهما

مناقشـة نتائج السؤال الأول: ما انماط القيادة لدى مديري المدارس الثانوية حسب نظرية بلانشرد وهيرسي؟

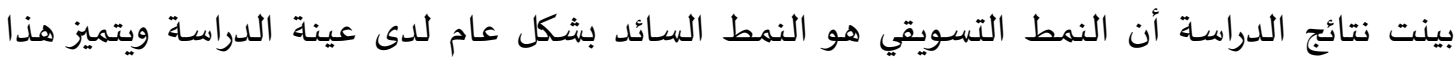

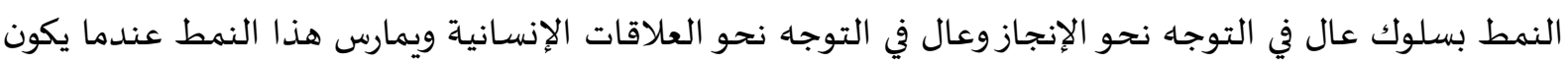

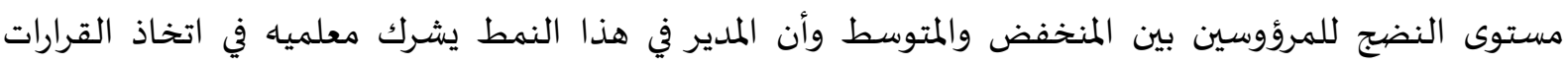

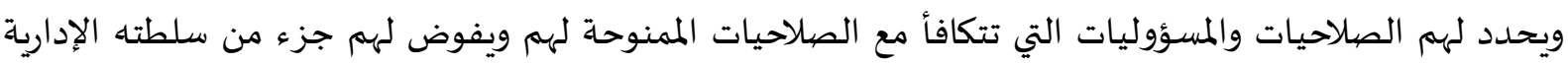
مع اهتمام بتوفير جو من الصداقة والتعاون والثقة والاحترام المتبادل بينه وبين المعلمين. 
إن المدير في هذا النمط ينظم فعاليات المدرسة من خلال زملائه ويتعاون معهم في تحقيق الأهداف المرسومة

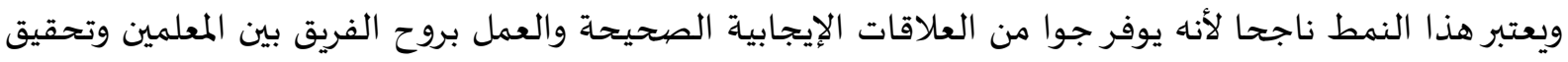

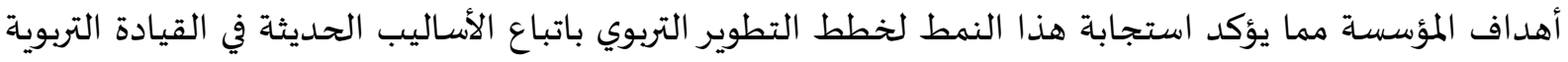
واستفادته من برامج التطوير التربوي وإيمانه بالنهج الديمقراطي في السلوك القيادي .كذلك قناعات التهات الإداريين

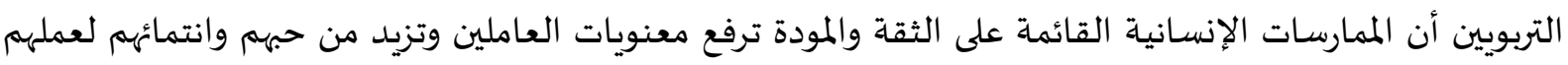

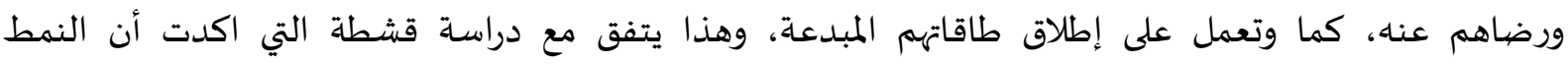

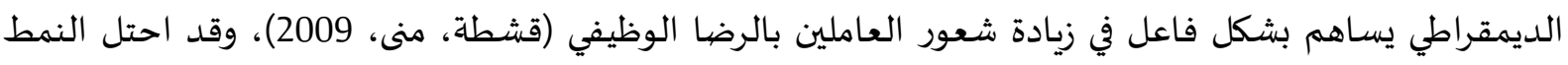

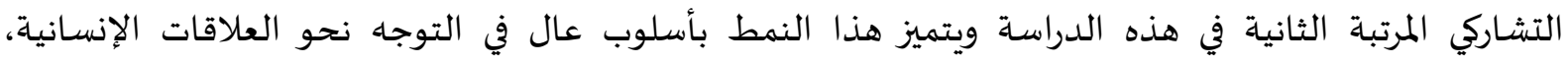

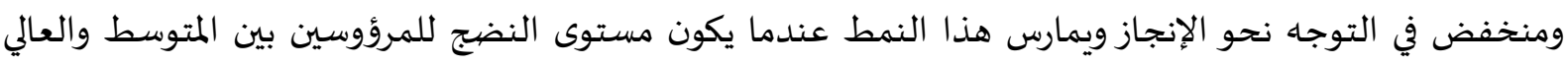

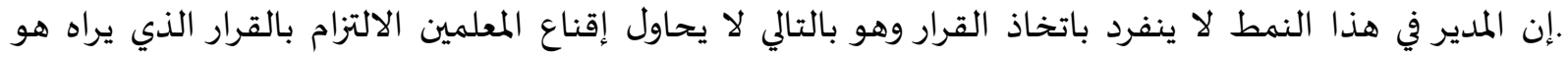

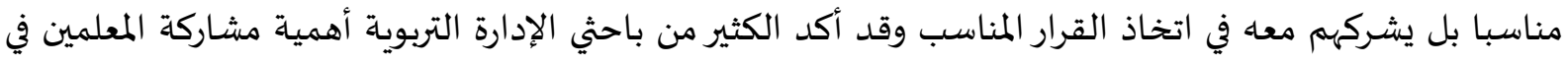

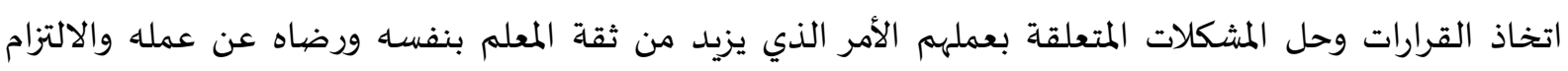

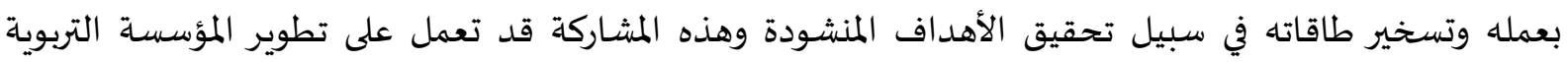

$$
\text { وتحقيق أهدافها وأهداف العاملين فيها. }
$$

أما النمط التسلطي فقد جاء في المرتبة الثالثة وهذا يعني أن العاملين هنا هم في مرحلة النضج الأولى إذ لا يلم العامل بعمله وكيف سيقوم به وهو لا يعرف الأهداف التنظيمية او رسالة التنظيم وغير قادر على القيام بالأعمال

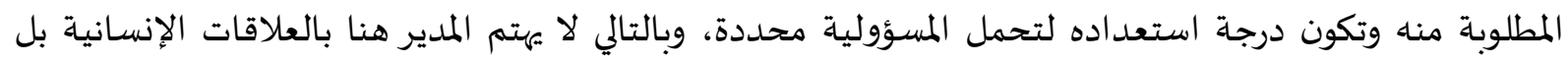

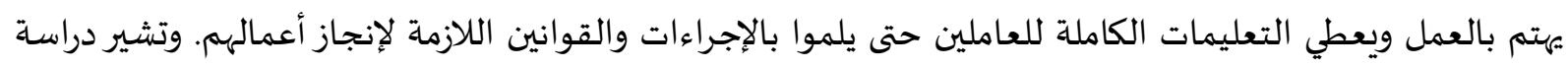

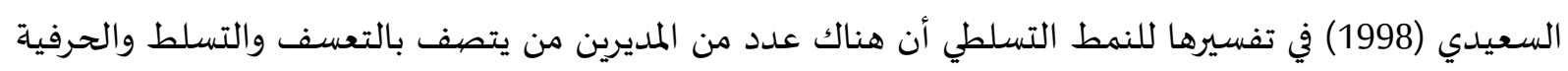

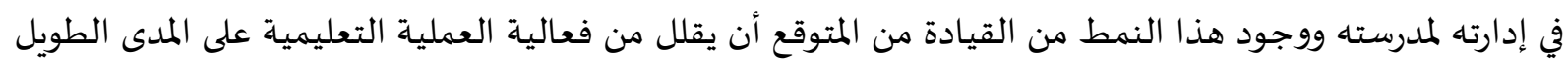

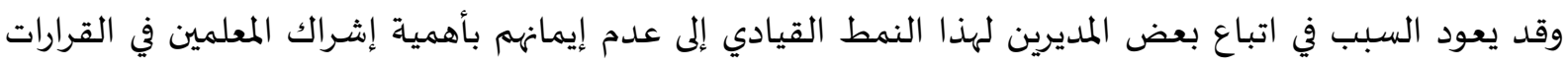

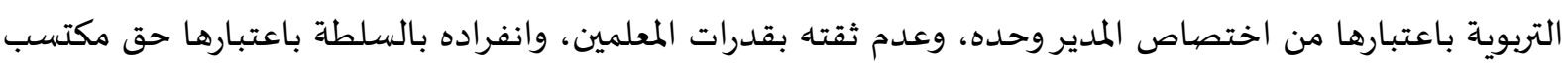

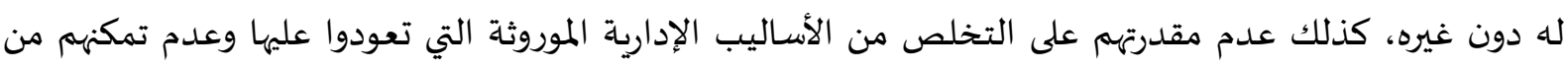

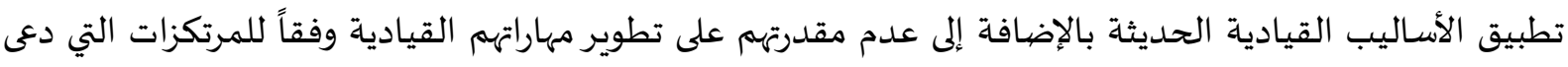

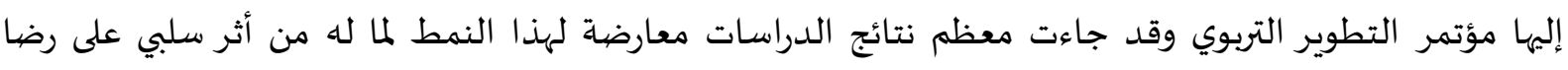

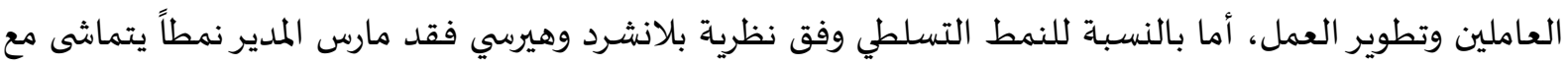
درجة النضج الوظيفي لدى العاملين . هذا وقد اشـارت نتائج الدراسة إلى أن النمط التفويضي قد الدئ احتل المرتبة الأخيرة لدى عينة الدراسة، وهذا

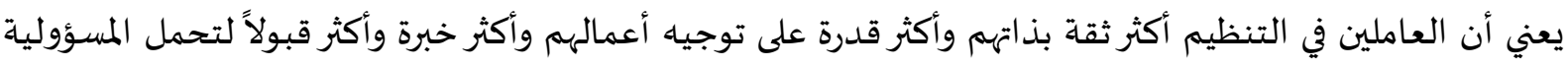

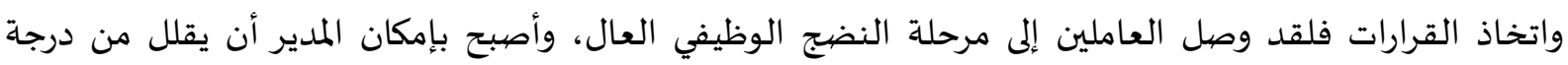

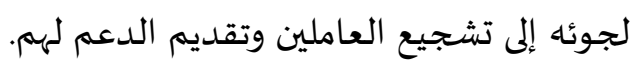

مناقشة النتائج المتعلقة بالسؤال الثاني: ما درجة الرضيا الوظيفي لدى المعلمين؟

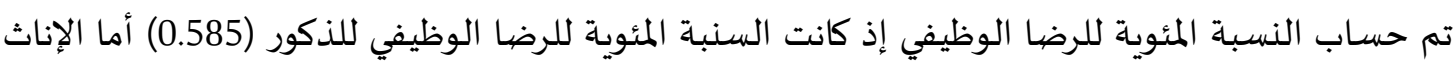
فكانت (0.628) أما من ناحية الاختصاص فكانت النسبة المئوية للاختصاص العلمي ذكور (0.583) أما الإناث 
(0.635) والاختصاص الأدبي ذكور (0.586) أما الإناث فكانت (0.627) يعتبر الرضا الوظيفي من المسائل المهمة

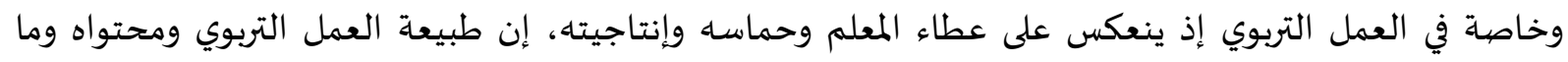

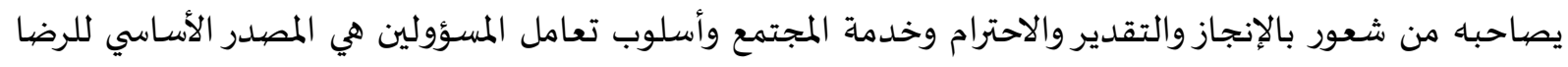

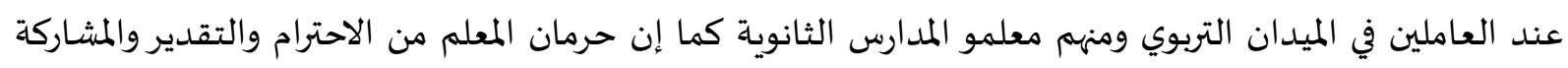

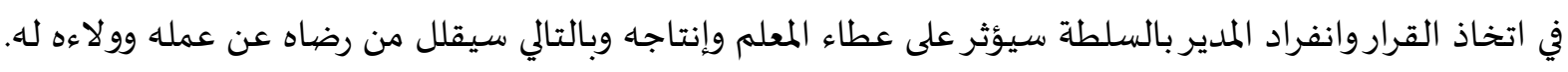

مناقشة نتائج السؤال الثالث: هل توجد فروق ذات دلالة إحصائية في الرضيا الوظيفي لدى العاملين تعزى

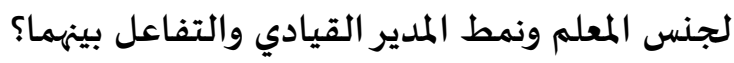

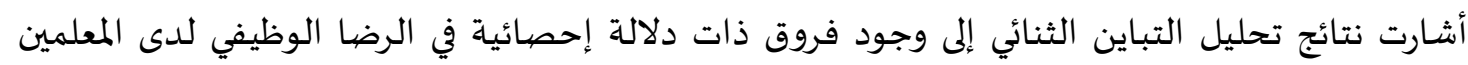

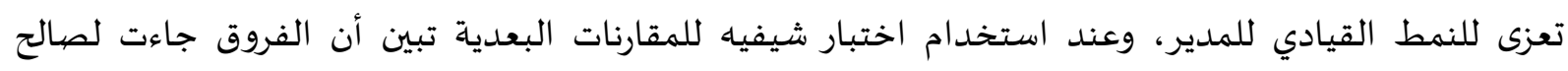

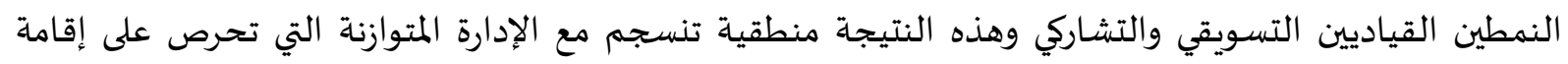
علاقات إنسانية ودية مع المعلمين في نفس الوقت الذي تحرص فيه على تحقيق أداء معقول من جانب المعان المعلمين

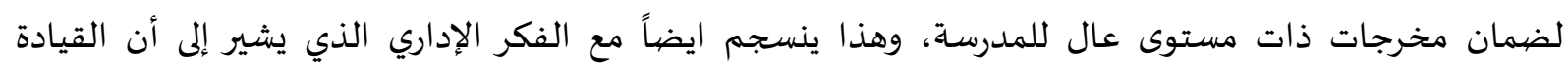
الجماعية (قيادة روح الفريق) توفر مستوى عال من الرضا والمعنويات المرتفعة للعاملين في مختلف المؤسسات. وتتفق هذه الدراسة مع معظم الدراسات مثل دراسة ونكلر (Winkler, 1983) ودراسة كلاوتر ( Klawitter,

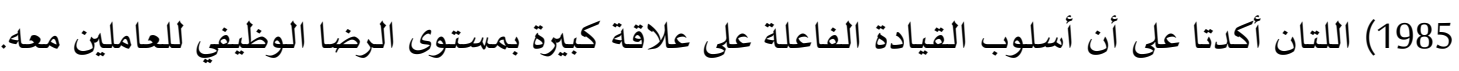

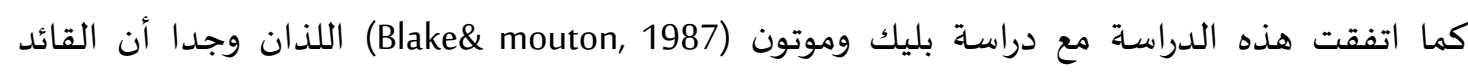
الديمقراطي يسعى إلى توضيح أهداف المؤسسة والاهتمام بالعاملين بمنهج ديمقراطي وهو يلجأ إلى الأفراد لإشراكهم بشكل جماعي هادف من أجل تحقيق الأهداف الأسـاسية للعمل. وهذا يتفق أيضا مع دراسة بلانشرد وهيرسي التي تؤكد على أن النمط القادئ القيادي التسويقي (Selling) يهتم بشكل كبير بالعمل والعلاقات الإنسانية. ويرى الطويل 1998 أن هذا النمط هو أفضل احتمال لتحقيق أفضل النتائج في معظم النظم التربوية،

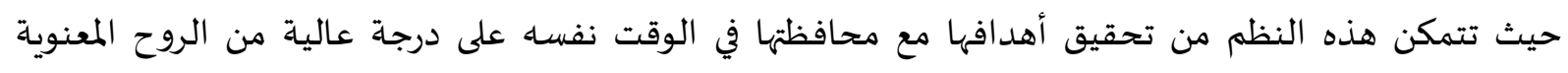

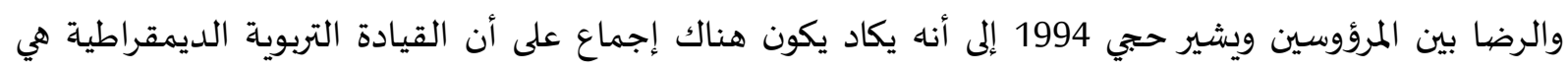

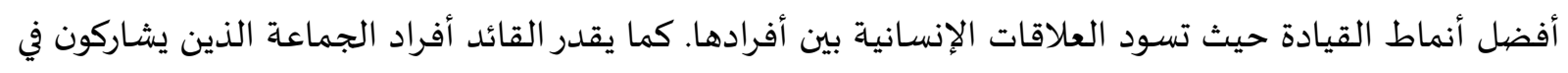

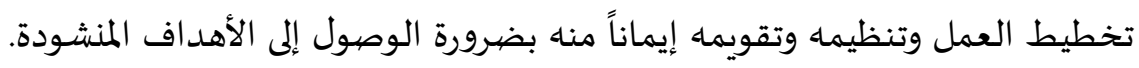

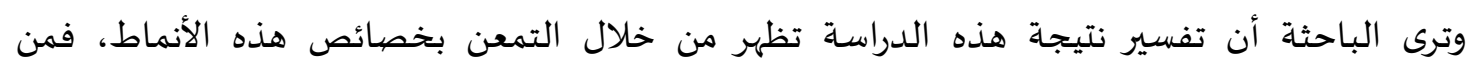

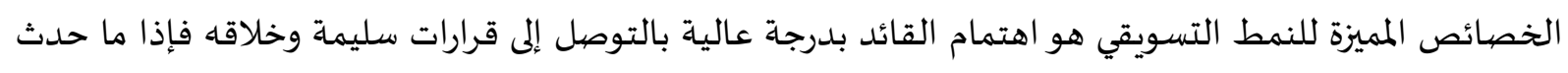

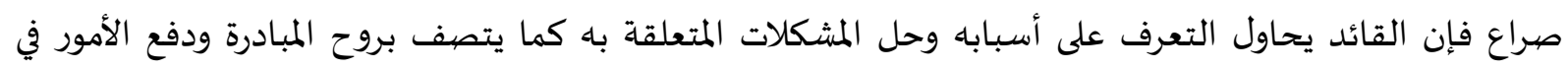

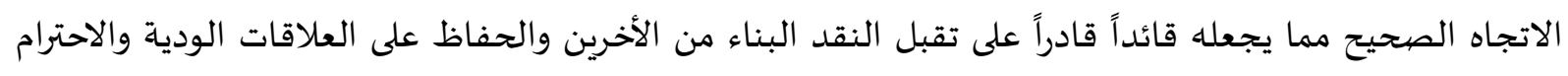
المتبادل.

أما النمط القيادي الثاني (التشاركي) فهو يحقق درجة متميزة من الرضا إذ أنه أسلوب عال في التوجه نحو

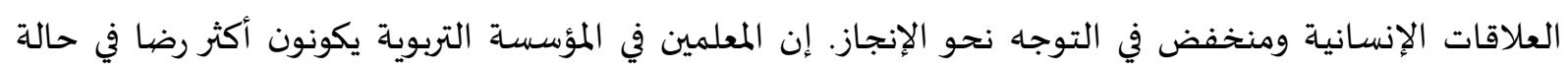

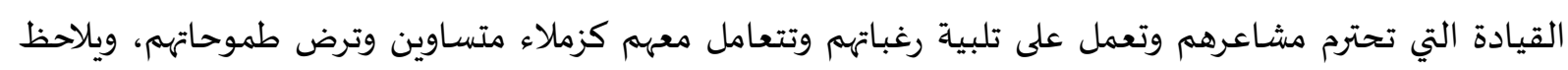

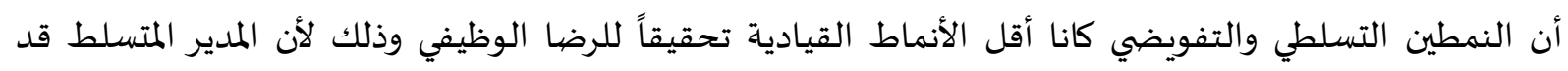


اهتم بالعمل دون الاهتمام بالعلاقات الإنسانية لأن العاملين لدياه في مرحلة النضج الأولي فهم لم يلموا بالأهداف

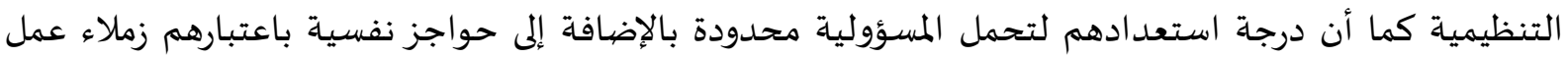

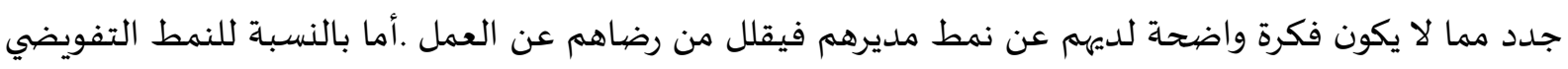
فقد كان أقل الأنماط

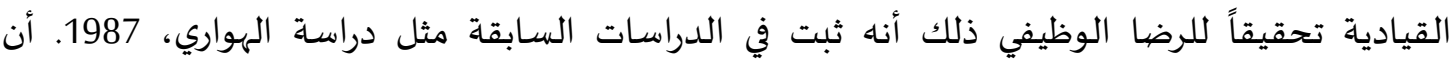

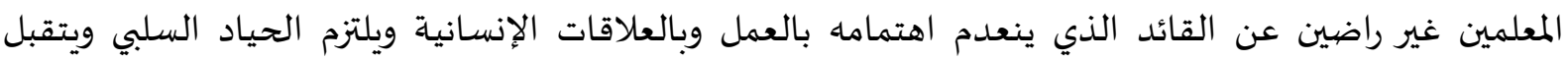

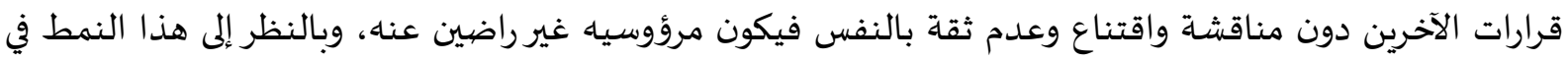

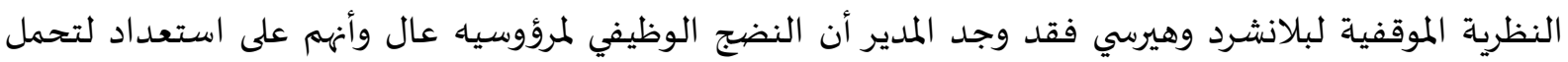

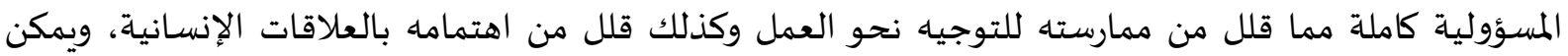
تعليل عدم رضا المعلمين عن نمط مديرهم، بأن المدير اعتقد أن مرؤوسيه وصهلوا مرحلة النضج الجيدة مما موكا يؤهله

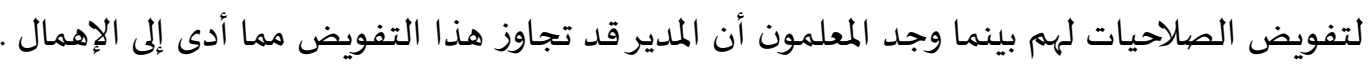

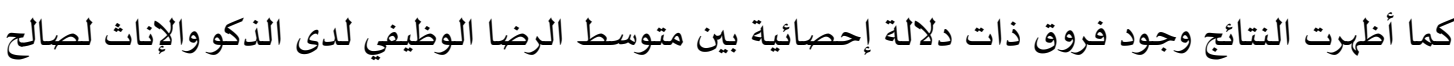

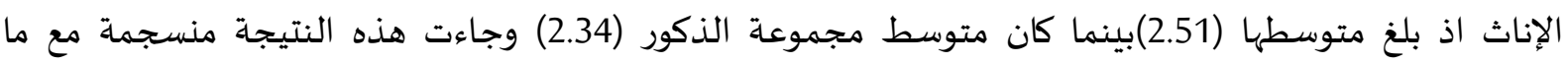

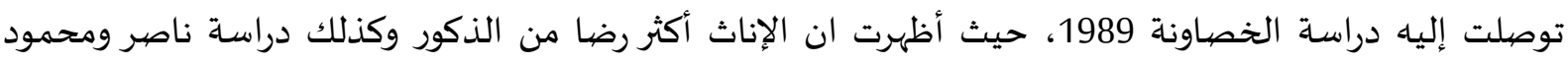

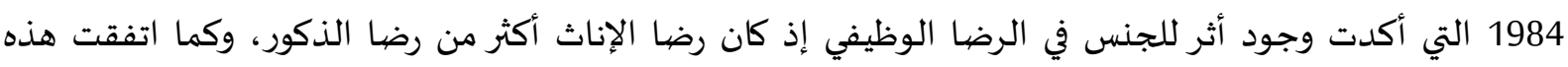

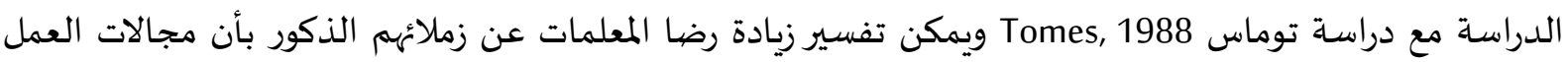

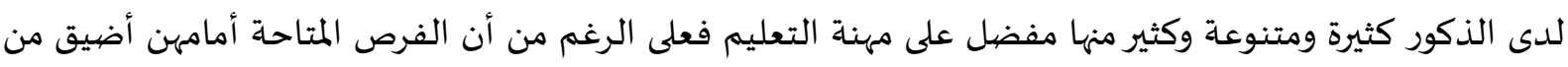

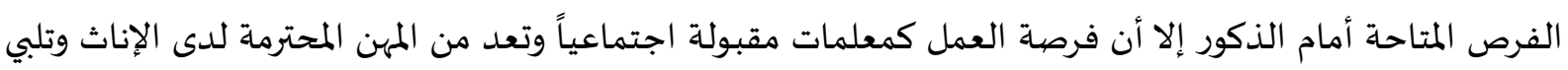
طموحات الكثير منهن الأمر الذي يزيد رضاهن عن عملهن.

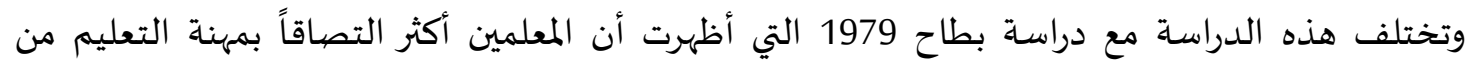

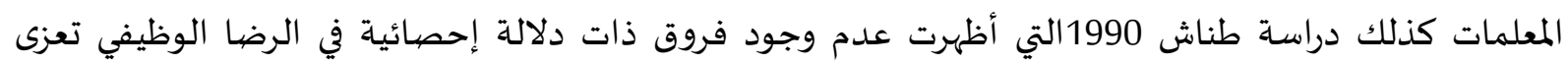
للجنس.

مناقشة نتائج السؤال الرابع. هل توجد فروق ذات دلالة إحصائية في الرضيا الوظيفي لدى المعلمين تعزى

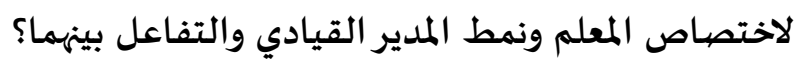

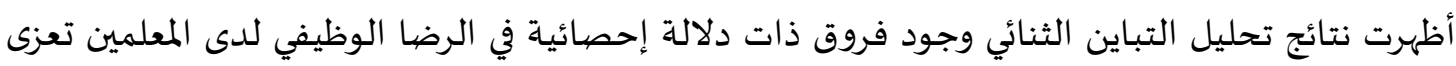

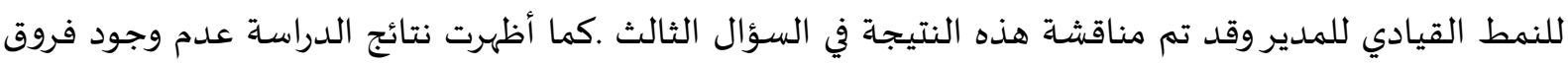

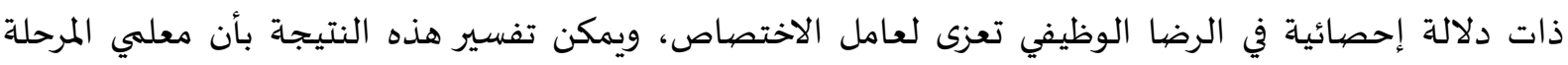

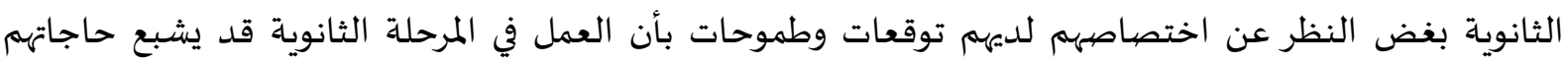

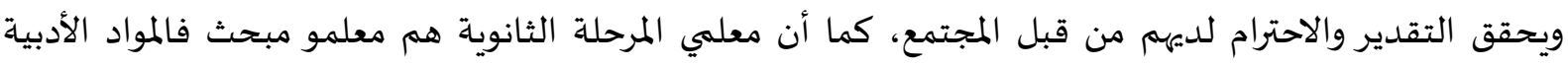

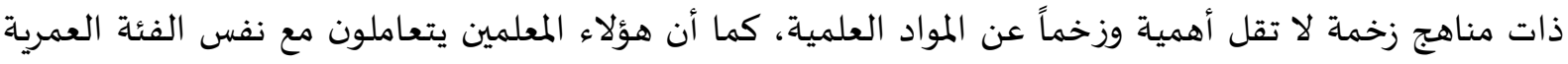
التي لها نفس الخصائص والحاجات، ويحصلون على نفس الامتيازات والتقدير باعتبارهم معلمي مرحلة ثانوية . 
أظهرت نتائج الدراسـة أن النمط التسويقي هو النمط الأكثر شيوعاً لدى عينة الدراسة وبناء عليه توصي

الباحثة بما يلي:

1- - ضرورة تدريب الإداريين على الأساليب القيادية الملائمة مع المؤسسة، وضرورة تطويرهم مهنياً عن طريق الحاقهم

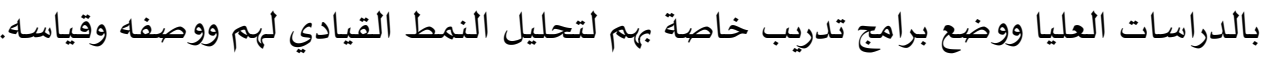
2- التركيز على السلوك القيادي التسويقي لمدير المدرسة وضرورة إشراك المعلمين في عملية اتخاذ القرارات وتلبية حاجاتهم ورغباتهم.

3- أظهرت نتائج الدراسة وجود فروق ذات دلالة إحصائية في الرضا الوظيفي لدى المعلمين تعزى للنمط القيادي

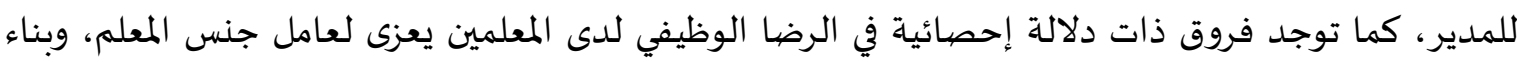
علياه توصي الباحثة بما يلي: - الكشف عن أسباب عدم رضا المعلمين الذكور عن مهنة التعليم والعمل على معالجتها.

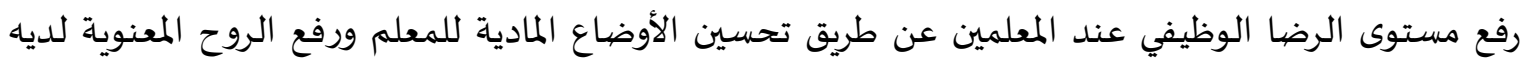
وتعزيز مكانة المعلم في المجتمع وتلبية طموحاته وحاجاته.

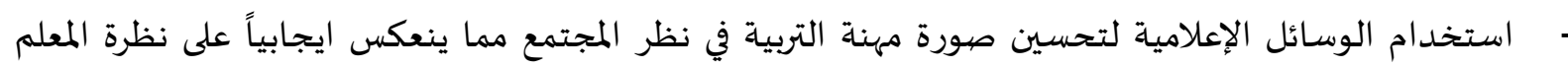
إلى تقدير المجتمع لمهنته وبالتالي اعتزازه بالمهنة وبالمدرساة. - أظهرت نتائج الدراسة عدم وجود فروق ذات دلالة إحصائية في الرضا الوظيفي لدى المعلمين يعزى لعامل

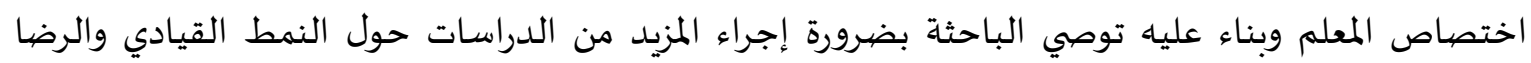

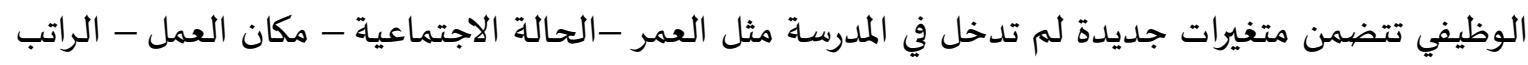

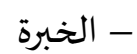

قائمة المراجع.

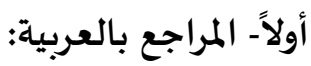
- الأشقر، وفاء محممد، 1994، الأنماط القيادية السائدة في جامعتي اليرموك والتكنولوجيا كما يراها أعضاء الهيئة التدريسية، رسالة ماجستير غير منشورة، جامعاة اليرموك، اربد، الأردن.

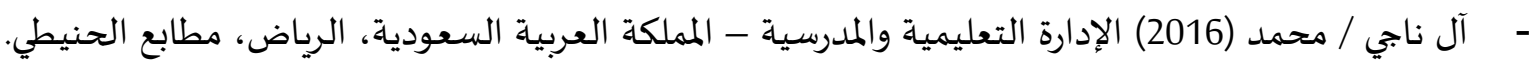

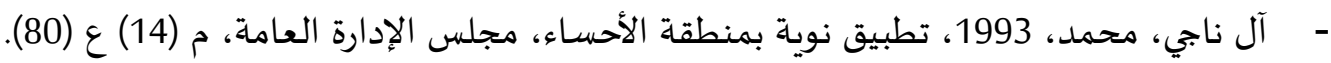

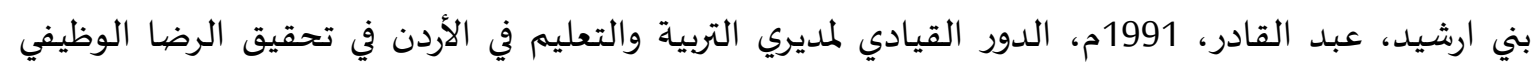
للعاملين معهم من وجهة نظر المعلمين، رسالة ماجستير غير منشورة، جامعة اليرموك، الأردن.

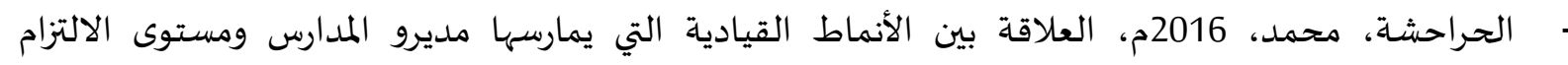

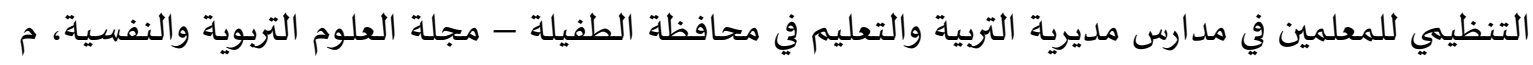

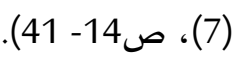
- الحوراني، غالب صالح، 1984م، تأثير النمط القيادي للمدير وضبط الوضع المدرسي على كل من رضا المعلمين وتحصيل التلاميذ في المدارس الثانوية في مدينة عمان، ماجستير غير منشورة، الجامعة الأردنية، عمان، الأردن. 
- ـ الخضري، سليمان وسلامة، محمد، 1982م، الرضا المهني لدى المعلمين في دولة قطر مجلة دراسات الخليج

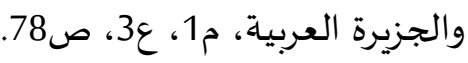
دره، عبد الباري، المدهون، موسى، الجزراوي، إبراهيم، 1994م، الإدارة الحديثة، مفاهيم وعمليات، منهج

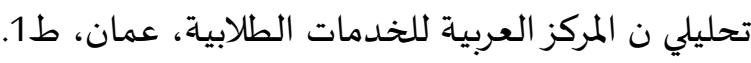

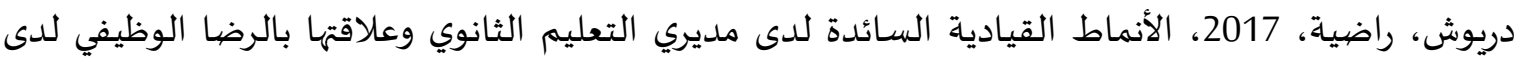
الأساتذة بالتعليم الثانوي، جامعة الجزائر.

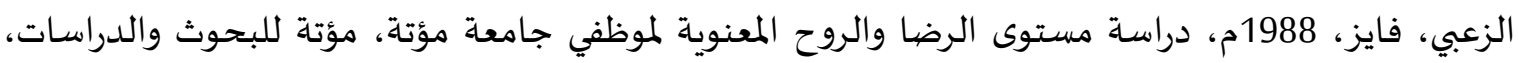
م3. ع. ع. 1.

زكريان، زوزبب مسروب، 1994م، الأنماط القيادية وعلاقتها بدرجة تطبيق الأسس النظرية لاستراتيجيات إدارة الصراع في المدارس الأساسية الحكومية والخاصة في منطقة عمان الكبرى، رسالة ماجستير غير منشورة،

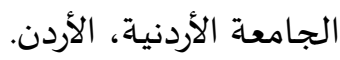
السالم، سالم محمد، 1997م، الرضا الوظيفي للعاملين في المكتبات الجامعية بالمملكاة العربية السعودية، جامعة الإمام محمد بن سعود الإسلامية، الرياض، السعودية.

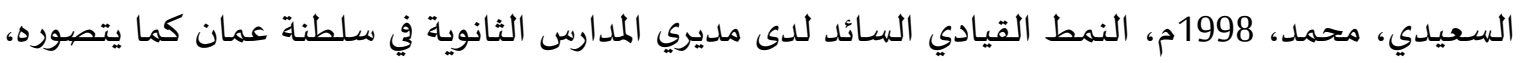
المعلمون العاملون معهم، رسالة ماجستير غير منشورة، جامعة السلطان قابوس، سلطنة عمان. السيد، حسام، 2017م، الأنماط الإدارية لمديري المدارس وعلاقتها بالرضا الوظيفي لدى المير المعلمين بمحافظة جنوب الباطنة، مجلة الثقافة والتنمية.

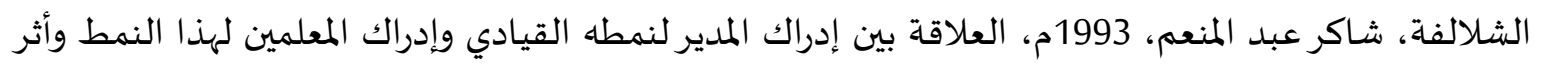
هذه العلاقة في مستوى الروح المعنوية لدى المعلمين وذلك في المارس الثانوية الأكاديمية التابعة لمديريتي التربية

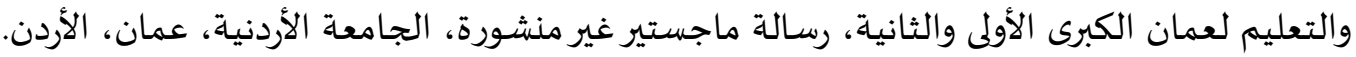

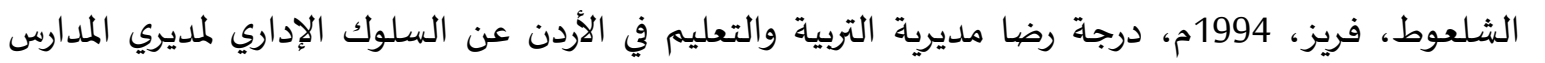
الثانوية الحكومية في مديرياتهم، رسالة ماجستير غير منشورة، الجامعة الأردنية، الأردن.

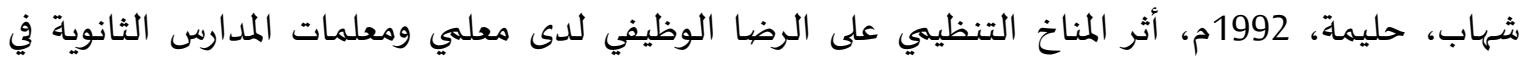
الأردن، رسالة ماجستير غير منشورة، كلية التربية، الجامعة الأردنية، الأردن. شوقي، طريق، 1992م، السلوك القيادي وفاعلية الإدارة مكتب غريب القاهرة. طناش، سلامة، 1990م، الرضا عن العمل لدى أعضاء هيئة التدريس في الجامعة الأردنية، دراسات الجامعة الأردنية، م17، ع.17. الطويل، هاني، 1998م، الإدارة التربوية والسلوك المنظم، ط 2، الجامعة الأردنية، عمان، الأردن. عباس، عوض، 1988م، في علم النفس الاجتماعي، دار المعرفة الجامعية، الإسكندرية. عبد الرحيم، زهير، 1996م، السلوك القيادي لدى مديري المدارس الأساسية في محافظة اربد وعلاقتها في الرضا الرها الوظيفي للمعلمين من وجهة نظر المعلمين، رسالة ماجستير غير منشورة، جامعة اليرموك، الأردن.

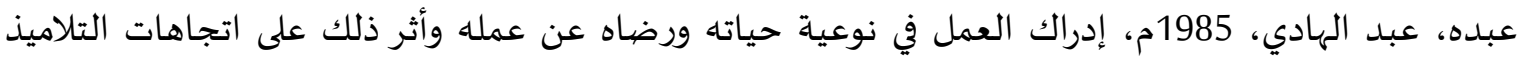
المدرسة الابتدائية، مجلة كلية التربية، المنصورة، العدد 6. - القريوتي، محمد، 1993، السلوك التنظيمي، دراسات السلوك الإنساني الفردي والجماعي، ط2، عمان، الأردن. 
قشطة، منى، 2009، درجة ممارسة مديري المدارس الثانوية لنمط القيادة التربوية في ضوء المعيير الإسلامية من

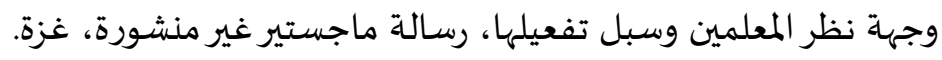

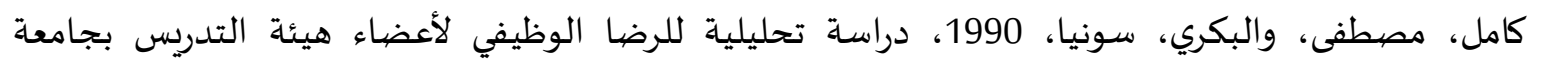

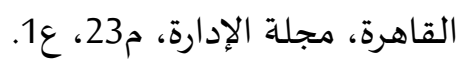

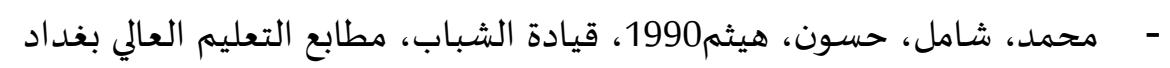

المغيدي، الحسن، 1996، أثر الأساليب القيادية في مستوى الرضا الوظيفي للمعلمين في محافظة الاحساء

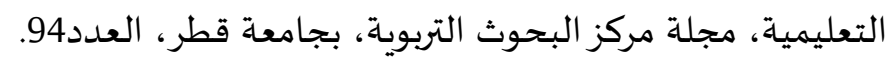

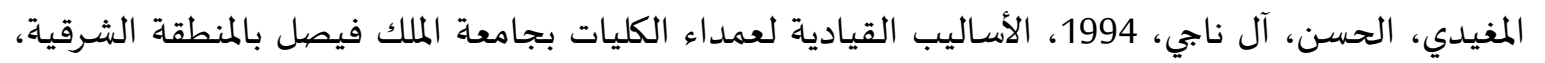

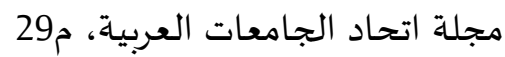
نبراوي، يوسف، 1989، ناظر المدرسة ومعضلة تعدد الأدوار، مجلة كلية التربية، جامعة الامارات العربية ع2،

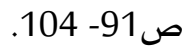

- ـ ـ ياسين فاطمة، 1992م الرضا الوظيفي لدى مديري المدارس الثانوية في الأردن، رسالة ماجستير غير منشورة،

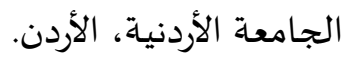

\section{ثانياً - المراجع بالإنجليزية:}

- Genzel, Mary C. 1998, Job Satisfaction of the Nursing Staff Development Educator ،D'youville College (1940) Degree, Ms, Pp98.

- Henry, W, K,1989, Leaders Shipstyles of Principals and Teacher Job Satisfaction in Christion Fundamental Is Academic Schools. Dissertation Abstracts International, (The University of Tennessec,51)4.

- Hughes, S.L.1996. Leadership Behaviorsary Prinpals As Perceived by Their Teachers (Men, Women) Dissertation Abstracts International, The University of Southern Mississippi,56.(11)

- james, G. (2004). relationship of principl transformaional leadership to school staff jobs at is faction, staff turnover, school performance.

- Korkmaz.mehmet,2007, the effects of leadership styles on organizational health, educational research quarterly.

- $\quad$ Kouzes, J.M. AND POSNER, B.Z.1987. THE LEADERSHIP CHALLENGE SANFRANCISCO JOSSY - BASS INC.

- Lamb, D.S.1993. The Relationship Between Inexperienced Teacher Job Satisfaction and Perception of Principal's Leadership Style Dissertation Abstracts, International the University Of North Carolina At Chaped Hill 54(4) P.1177.

- Lovell, J.T. And Willes, 1983. Supervision for better school (5th ed) Englewood cliffs, New Jerseuy: Prentice Hall. P.66.

- Mendel, p.c. 1988, An Investigation of Factors That Influence Teacher Morale and Satisfaction with Work Conditions Dissertation Abstract International, 48(4) ،P,2207. 
- Mitchell, James, Byron, 1989, Teacher Job Satisfaction and Teachers Rapport with The Principal in Relationship, To Principals, Leadership Styles and School Enrollment Size in Tennessee Public Secondary Schools Dissertation Abstracts International, 50(6). P.1512.

- Muchinsky ،P.M. (1990) ،Psychology Applid To Work, California Cole Publishing Co.

- Palmer ،r. 1995. " The Relationship Between Principals Leadership Style and Faculty Perception of Principals Effectiveness" Dissertation Abstract International, The University of Mississippi,56 (9). P. 3400 .

- Perkins, C ،M ، (1991) Astudy To Investigate Experienced Teachers Job Satisfaction and The Teachers Perception of Their Principals Leadership Style Dissertation Abstracts International the University Of North Carolina At Chapel Hill, 52(12). P. 4171.

- Phillips, S, 1987, District Level Policies and Practices PhiDIta Kappan, 68,4, P.300- 304.

- Secumski, K.E.1993. The Relationship Between Elementary School Teachers Job Satisfaction, Principals Managerial Styles and Student Achievement, Dissertation Abstracts, International ,54 (5) P. 1625

- Vinze, Linda Sane, 1998, The Relationship of Participation in Decision Making Through Shared Governance to Job Satisfaction Among Primary Care Nursing State, Nova South Eastern University (1191) Degree Bapp. 1914. Umr Compang 58,3, P,198.

- Winkler, A.L.1983 The Relationship Between Elementary School Teacher Perceptions of Principal Leadership Style Adaptavity and Teacher Job Satisfaction with Supervision Dissertation Abstract International,45. (03), P.720. 